\title{
The Roles of State Aid and Local Conditions in Elementary School Test-Score Gaps
}

\author{
Katharine Bradbury
}

\begin{abstract}
:
Equal educational opportunity is a core American value. Yet many children of low-income or minority racial or ethnic status attend public schools that are lower quality compared with those that white children or high-income children attend. And data indicate that, on average, lowincome or minority children score lower on states' elementary-school accountability tests compared with higher-income children or white children. Such test-score gaps serve as evidence of unequal educational opportunity. This study uses information from metropolitan areas and from school districts to understand which factors are strongly related to the size of racial and socioeconomic test-score gaps. One key factor is the degree to which state aid to school districts is distributed progressively - that is, distributed disproportionately to districts with high fractions of students living in poverty - with progressive distributions associated with smaller test-score gaps in high-poverty metros or districts. Second, test-score gaps are larger in metropolitan areas and districts where poverty segregation is greater, that is, where, compared with white children or higher-income children, minority children or low-income children go to school with, or are in school districts with, more students from low-income families.
\end{abstract}

JEL Classifications: H75, H77, I22, I24, I28

Keywords: inequality of opportunity, student test-score gaps, state aid to public schools, socioeconomic segregation, racial segregation

Katharine Bradbury is a senior economist and policy advisor in the research department of the Federal Reserve Bank of Boston. Her email is Katharine.Bradbury@bos.frb.org.

The author thanks Jeff Thompson and all her colleagues in the New England Public Policy Center for very helpful comments. Morgan Klaeser provided excellent research assistance. Elizabeth Pancotti assisted with early data exploration.

This paper presents preliminary analysis and results intended to stimulate discussion and critical comment.

The views expressed herein are those of the author and do not indicate concurrence by the Federal Reserve Bank of Boston, the principals of the Board of Governors, or the Federal Reserve System.

This paper, which may be revised, is available on the website of the Federal Reserve Bank of Boston at https://www.bostonfed.org/publications/research-department-working-paper.aspx. 
Equal educational opportunity is a core American value. Yet analysts observe that many children of lowincome or minority racial or ethnic status attend public schools that are lower quality compared with those that white children or high-income children attend. Public elementary and secondary education is a state-local function in the United States, with variations in quality across and within states. In all U.S. states except Hawaii, local school districts provide and fund the public schools, and state funds augment local resources. ${ }^{1}$ The level of state support varies considerably across the states, and institutional arrangements - from allocation formulas to curriculum oversight-also vary widely.

Earlier research established that state school-aid reforms in the 1970s and 1980s altered school spending patterns and, by altering spending, strongly influenced student outcomes such as school completion, adult wages, and adult poverty, especially for low-income children (Jackson, Johnson, and Persico 2016). A more recent analysis of reforms in the 1990s and 2000s similarly shows substantial positive effects of aid reforms on school spending and student achievement in low-income districts (Lafortune, Rothstein, and Schanzenbach 2018).

Key attributes of state aid to local public schools include the basic state-aid formula's level of funding, the extent to which redistribution counteracts local revenue capacity disparities, and the degree to which the state provides additional per-pupil funds to districts that educate high-cost students. "High cost" in this context typically refers to students from families living in poverty, English-language learners, and those with special needs.

Students' educational achievement depends on a host of influences in addition to the influence of funding (whether provided by state or local government). These include teacher quality, school peers, family background, parental support, and neighborhood and community characteristics. Children whose parents are able to provide "enrichment" experiences beyond school tend to do better in school; communities can provide (or lack) role models highly engaged in economic activity. And children of different races or economic statuses may attend different schools and/or experience different school quality, even within a single district.

\footnotetext{
${ }^{1}$ Hawaii has full state funding in its one statewide school district.
} 
Using variation among school districts and among metropolitan areas in key outcome measures, specifically gaps between test scores for students of different races and between test scores for students who are economically disadvantaged and those who are not, this paper builds on earlier research to investigate the roles of state school aid and other school, parental, and community inputs in public-school outcomes. The test-score data are available from the Stanford Education Data Archive (SEDA), for which researchers have carefully computed "adjusted" metropolitan area and district-level test scores and test-score gaps that can be compared reliably across states, even though the tests are state-specific. ${ }^{2}$ This research builds on earlier research produced by Stanford author Sean Reardon and others that finds racial test-score gaps strongly related to local conditions, especially racial segregation, racial differences in exposure to poverty at the school level within a district (Reardon 2016) and at the district level within a metropolitan area, and notably racial differences in exposure to concentrated poverty (Reardon, Weathers, et al. 2019).

The current paper focuses on average test-score gaps by race/ethnicity or economic disadvantage over the full SEDA study period (the 2008/09 school year through the 2015/16 school year) for mathematics and English language arts and grades 3 through 8 combined. The contribution of this paper compared with the work from the Educational Opportunity Project at Stanford University is its investigation of the relationship between state aid to local public schools and test-score gaps; the research by Reardon and colleagues does not investigate state school aid. At this writing, the analysis of economic disadvantage gaps in this paper is also an innovation, but the Stanford project's researchers are likely to release research on economic disadvantage gaps parallel to their research on racial test-score gaps in the near future.

The remainder of this paper proceeds as follows. Section I summarizes related literature. Section II presents hypotheses about factors contributing to school achievement and related data. Section III describes the regression results for metropolitan area test-score gaps by race and socioeconomic status and also for gaps at the individual district level. Section IV concludes with a discussion of the findings' possible policy implications.

\section{Related Literature}

Several strands in the existing literature are closely related to the analysis of test-score gaps reported

\footnotetext{
${ }^{2}$ Data citation: Reardon, Ho, et al. 2019.
} 
here. One strand focuses on funding and specifically state aid to local public schools; another relates to parental "inputs" to children's education; and a third documents the importance of children's neighborhood and community in their academic success.

\section{A. School Funding and State Aid Literature}

Jackson (2018) summarizes a long list of papers, contrasting earlier (pre-1995) descriptive school-aid research with more recent quasi-experimental analyses of school finance reforms. He argues that while the results of earlier studies of the association between school spending and school outcomes are mixed, they do "indicate a real and economically meaningful [positive] association between school spending and student outcomes" (p. 2). Nonetheless, he argues, those earlier studies do not establish a causal relationship between spending and outcomes because they are correlational (observational) in nature. To overcome these difficulties, he argues, researchers need to rely on "exogenous (i.e., external) shocks to school spending that are both (a) unrelated to other determinants of student outcomes, and (b) not driven by the decisions of the individual families under study" (p. 3). That is the approach of the more recent studies, which use school finance reforms as their exogenous shocks to school spending. On the basis of these studies, Jackson concludes that there is a causal link between increased school spending and improved student outcomes.

While based on reforms of state school aid, these studies do not examine specific state-aid formula elements but rather use reforms as exogenous shifters, allowing for identification of causal effects of state-aid dollars on school spending and student outcomes. Jackson, Johnson, and Persico (2016), whose study is a prime example, look at "adult outcomes of cohorts that were differentially exposed to school finance reforms" (p. 157) enacted in the 1970s and 1980s to quantify the effects of additional school spending on years of school completed, adult wages, and adult poverty incidence. They find economically important effects: "[F]or low-income children, a 10\% increase in per pupil spending each year for all 12 years of public school is associated with 0.46 additional years of completed education, 9.6\% higher earnings, and a 6.1 percentage point reduction in the annual incidence of adult poverty" ( $p$. 160).

LaFortune, Rothstein, and Schanzenbach (2018) similarly look at finance reforms of the 1990s and early 2000s; they find that the reforms led to increases in school spending in lower income districts that were greater than the spending increases in richer districts, and they find corresponding increases in relative test scores in low-income districts: "Ten years after a reform, relative achievement of students in low- 
income districts has risen by roughly 0.1 standard deviation, approximately one-fifth of the baseline gap between high- and low-income districts. The implied impact is between 0.12 and 0.24 standard deviations per $\$ 1,000$ per pupil in annual spending" (p. 4). However, they note "no discernable effect of reforms on statewide achievement gaps between high- and low-income students or between minority and white students" (p. 4), in large part, they argue, because low-income and minority students within states are not heavily concentrated in the low-income districts where funding reforms raised spending. The earlier reforms focused more on "equity," while the later ones were based on arguments of "adequacy," but both had similar effects of raising spending in lower income, low-spending districts, particularly those with fewer local resources to fund schools under the prevalent property-tax-financed systems.

Jackson (2018) cites six additional multistate studies that use school finance reforms to examine spending and outcomes, only one of which fails to find a positive and significant effect of spending on student outcomes. ${ }^{3}$ Jackson also lists two single-state studies of Michigan's school finance reforms' effects on test scores. Those studies find significant and positive effects on test scores of the increases in spending among low-spending districts brought about by the reforms ${ }^{4} \mathrm{~A}$ recently published study (Brunner, Hyman, and Ju 2020) also finds significant positive effects on test scores (especially those of students in low-income districts) of increases in school spending resulting from school finance reforms nationwide.

Establishing that state school-aid reforms affect district spending and student outcomes is a key first step to further examination of the effects of specific attributes of state aid to public schools, such as the degree to which the aid funds are tilted toward districts with fewer local resources and whether (and how much) the aid is responsive to education cost differentials among districts, notably the relative costs of educating specific types of students. Duncombe, Lukemeyer, and Yinger (2004), for example, lay out the three approaches that states use to evaluate education costs: professional judgment, successful schools examples, and direct cost estimation. Using the third approach, they quantify the extra cost associated with teaching students who are living in poverty, have limited English proficiency, or have a disability and indicate that 18 states used "weights" in their aid formulas to provide greater funding to

\footnotetext{
${ }^{3}$ The exception is Hoxby (2001), who finds the estimated effects of equalization on student achievement (measured as dropout rates) to be "generally weak."

${ }^{4}$ Roy (2011), however, notes that the associated increase in achievement is very small, considering the very substantial increases in spending. In a similar vein, five earlier state studies reported in Yinger (2004) find school finance reforms (in Kentucky, Michigan, and Vermont among others) reduced disparities in per-pupil spending among districts, but had little to no effect on test-score disparities.
} 
districts with more disadvantaged students. More recently, Zhao (2020) estimates education cost differentials among school districts in Connecticut, finding that student poverty is an important contributor to education costs and suggesting that cost measures can inform the state's school-aid program. The existence of cost differentials implies that higher-cost districts would need higher perpupil expenditures to achieve the same educational outcomes.

While earlier work shows that school spending affects children's economic success and, in a few cases, school achievement, very little research work investigates how specific funding sources (local, state) and allocation methods (redistributive extent, formula types) relate to students' test scores and, especially, to test-score gaps between races and between students who are not economically disadvantaged and those who are. This paper extends that earlier work in a cross-sectional context to ask how characteristics of state aid to local school districts, as well as district and metro-area school and neighborhood characteristics, are related to test-score gaps. The school-finance measure used here-as discussed in more detail below-indicates the degree to which each state's school-aid revenues are directed to school districts with high poverty relative to districts with low poverty, testing the hypothesis that aid distributions providing relatively more aid to high-poverty districts are associated with smaller racial and economic test-score gaps, when controlling for other factors expected to influence gaps.

\section{B. Literature Related to Parental and Neighborhood/Community Inputs to Education}

Educational achievement and test scores obviously depend on many factors in addition to funding. A considerable literature examines the influence of parents, other (non-dollar) aspects of school quality, and neighborhood/community characteristics on students' school success.

Reardon (2011), Rothstein (2018), and Hanushek et al. (2019) document the importance of parental resources (income and, more broadly, socio-economic status) in determining student achievement. In particular, Reardon (2011) compiles earlier research on test-score gaps between children of highincome parents and children of low-income parents, and concludes that socioeconomic gaps have widened considerably since the 1970s. He offers several partial explanations, one of which relates to high-income parents' increasing investments in enrichment activities for their children. Rich parents can provide educational toys, read to and talk to their children more in the years before they start school, and provide more after-school and summer experiences during the $\mathrm{K}-12$ years. Kaushal, Magnuson, and Waldfogel (2011), for example, document "substantial income-related gaps in education-related items and activities" (p. 187). 
Neighborhood characteristics also affect children's academic and adult success. Burdick-Will et al. (2010) review a range of experimental, quasi-experimental, and observational studies and argue that neighborhoods matter to children's educational success in some contexts; specifically, neighborhoods of very concentrated economic disadvantage may depress children's test scores. In addition, the U.S. Department of Housing and Urban Development's Moving to Opportunity experiment finds that although students' test scores did not improve in the short run after a move from a high-poverty neighborhood to a low-poverty neighborhood (Sanbonmatsu et al. 2006), longer exposure to lowerpoverty neighborhoods did enhance students' longer-term outcomes, such as college attendance and earnings (Chetty, Hendren, and Katz 2016). ${ }^{5}$

A long line of research, brought to public attention by the 1966 Coleman Report and continuing since, measures and attempts to explain racial test-score gaps. For example, a report from the Educational Testing Service (Barton and Coley 2010) documents shrinkage in Black-white test-score gaps in the 1970s and 1980s, and very little progress since. Lee (2004) reports on the same Black-white (and Hispanic-white) test-score-gap trends over the 1970s, 1980s, and 1990s, and discusses a range of possible explanations for the shrinkage and leveling. Card and Rothstein (2007) find that racial segregation, especially across neighborhoods, has a consistently negative impact on Black-white gaps in SAT scores, based on data for a 1998-2001 cohort of high school graduates. Baker, Farrie, and Sciarra (2016) ask similar questions about test-score gaps between low-income and higher income children. Johnson (2019) provides evidence that court-ordered desegregation in many U.S. urban school districts reduced Black-white test-score gaps, and that court reversals in recent decades have stalled the narrowing.

Sean Reardon and his colleagues at the Educational Opportunity Project at Stanford University analyze racial gaps in test scores in several papers (see https://edopportunity.org/research/), concluding that a key causal factor is racial differences in in-school exposure to poverty. Reardon (2016) reports that "racial segregation is strongly associated with racial achievement gaps, and the racial difference in the proportion of students' schoolmates who are poor is the key dimension of segregation driving this association" (p. 47). His estimated coefficients (based on 2009-2012 pooled data in 300-plus metro areas) imply that a 20 percentage point racial difference in exposure to poverty (Black-white or Hispanic-

\footnotetext{
${ }^{5}$ Specifically, Chetty, Hendren, and Katz (2016) find that moving from a high-poverty to a low-poverty neighborhood before the age of 13 raised a person's annual individual earnings by 31 percent in their mid-twenties compared with the control group and increased college attendance by 2.5 percentage points (relative to 16.5 percent attendance among the control group).
} 
white) -the average metro-area difference in his sample-corresponds to an achievement gap of 0.12 to 0.15 standard deviation, or "roughly one-fifth of the average racial achievement gap" (p. 20). The Stanford project's most recent paper along these lines (Reardon, Weathers, et al. 2019) confirms a strong role for racial differences in exposure to poverty in explaining district, county, and metro-area racial test-score gaps.

\section{What Factors Contribute to Educational Achievement? Hypotheses and Data}

The current analysis begins with a simple education production function positing that area $m$ 's average test score A (school output = achievement) or the area's average test score for a specific subgroup $s$ is a function of a range of inputs, including school quality (Q) and student/family (F) and community/neighborhood (C) inputs related to that subgroup.

$$
A_{m s}=f\left(Q_{m s}, F C_{m s}\right)
$$

In this model, test-score gaps $G$ between racial or socio-economic groups (for example, white and Black) in an area should depend on differences between the groups in those types of inputs:

$$
G_{m w B}=A_{m w}-A_{m B}=g\left(Q_{m w}-Q_{m B}, F C_{m w}-F C_{m B}\right)
$$

School-related inputs may differ because minority and white students reside in different districts within the metro area or attend different schools within districts. ${ }^{6}$ Family and community inputs may differ because parents of minority and white students have different educational and economic advantages or disadvantages, both across districts and within districts.

The paragraphs below discuss and describe test-score gaps and the contributing factors in turn, and describe the data available to measure them. That discussion yields a more detailed estimating equation, outlined at the beginning of section III.

\section{A. Test Scores}

Partly as a result of No Child Left Behind, all U.S. states require public-school students to take standardized tests to evaluate school and district progress toward proficiency, on average and for population subgroups. These tests and the standards by which they are evaluated are state-specific,

\footnotetext{
${ }^{6}$ Quality may also differ because subgroups receive different qualities of education within a school; this is not observable/measurable in the current research context.
} 
meaning that raw test scores cannot be compared across states. However, researchers at Stanford University have published measures of test scores that they adjusted through a detailed and comprehensive statistical approach to be comparable across states (Reardon, Ho, et al. 2019). The current analysis uses these measures from the Stanford Education Data Archive (SEDA) at the metropolitan-area and school-district levels, aggregated over grades 3 through 8, school years 2008/09 through 2015/16, and the subjects English language arts (ELA) and math. ${ }^{7}$ The current analysis focuses on the Stanford researchers' estimates of within-metro-area and within-district test-score gaps between whites and Blacks, between whites and Hispanics, and between students who are not economically disadvantaged and those who are economically disadvantaged. ${ }^{8}$ They release these gap measures for districts and metro areas where the number of subgroup members is sufficient for reliable gap estimates; ${ }^{9}$ they also publish standard errors for the gap estimates. SEDA adopts each state's definition of "economic disadvantage" in compiling scores for that subgroup and their counterparts who are not economically disadvantaged.

While remaining somewhat agnostic about the relationship between test scores and learning or achievement, ${ }^{10}$ this paper examines the correlates of racial and economic test-score gaps to better understand the factors related to these widely used measures of school success and unequal attainment of such success. That inequality in test scores by race or income, especially when some differences in "educational inputs" are controlled for, undoubtedly reflects a degree of unequal educational opportunity. Examination of gaps provides information regarding factors related to that inequality of opportunity; that is, making a test-score gap rather than a subgroup's test-score level the dependent variable asks directly about relationships between explanatory variables and unequal opportunity.

Table 1 reports average metropolitan-area test-score gaps and test-score levels for all metropolitan areas for which SEDA was able to estimate each gap measure, about 900 metropolitan areas across the nation. ${ }^{11}$ The test-score numbers reported in Table 1 are in standard deviation units for a nationwide

\footnotetext{
${ }^{7}$ In addition to being available for districts and metro areas, average test scores are available for schools, for counties, and for commuting zones.

${ }^{8}$ SEDA's convention is to measure gaps by subtracting the scores for students facing racial or economic disadvantages from the scores for relatively advantaged students, so a bigger (positive) test-score gap indicates a greater degree of relative disadvantage for Black, Hispanic, or economically disadvantaged students. Hence the gaps are white-Black, white-Hispanic, and not economically disadvantaged-economically disadvantaged.

${ }^{9}$ SEDA also publishes male-female and white-Asian gap estimates. In addition to being available for school districts and metro areas, these gap measures are available for counties and commuting zones.

10 "Agnostic" in the sense that test scores reflect not only learning and educational achievement, but also testtaking ability.

${ }^{11}$ Data in Table 1 are restricted to metro areas in the regression samples of Tables 3 through 5; hence some
} 
student cohort, multiplied by 100 (to reduce difficult-to-read leading zeroes in this table and in the coefficient estimates). The nationwide student cohort includes students who were in the fourth grade in 2009, 2011, and 2013; their average score is set equal to zero by definition. ${ }^{12}$ The "Weighted All" line in each panel reports weighted average test-score gaps across all metropolitan areas in each sample, where the weights reflect the reliability of SEDA's estimates of test-score gaps. ${ }^{13}$ That the weighted gaps are larger than the unweighted measures indicates the more reliably estimated gaps are larger, on average, than gaps that are less tightly estimated.

Weighted average test-score gaps between white and Black students and between not disadvantaged and economically disadvantaged students amount to 0.7 and 0.6 standard deviation (shown as 69.5 and 63.5 in the table), respectively-fairly large discrepancies-and the average gaps vary substantially among regions. White-Hispanic test-score gaps are somewhat smaller on average, at just over half a standard deviation. Test scores for minority or disadvantaged students are negative on average, meaning that the group average for each of those categories of students falls below the cohort-standard average score, while white students and students who are not economically disadvantaged score well above the cohort standard, on average. ${ }^{14}$

The table reports averages across metro areas grouped by census division, with the East South Central division (80 to 90 metros in Alabama, Kentucky, Mississippi, and Tennessee) showing the smallest average racial test-score gaps in metropolitan areas, the South Atlantic division (about 155 metros in

metros for which SEDA publishes gap estimates are omitted here because they lack data on one or more explanatory variables.

12 The scores are "standardized within subject and grade, relative to the average of the three cohorts in our data who were in 4th grade in 2009, 2011 and 2013. We use the average of three cohorts as our reference group because they provide a stable baseline for comparison. This metric is interpretable as an effect size, relative to the grade-specific standard deviation of student-level scores in this common, average cohort. For example, a [school district] with a mean of 0.5 [50 as rescaled in Table 1] represents a [district] where the average student scored approximately one half of a standard deviation higher than the national reference cohort scored in that same grade" (p. 30, Fahle et al. 2019). As noted earlier, the current analysis uses pooled scores, combining all grades, subjects, and years.

${ }^{13}$ The weights are inversely proportional to the square of the standard error of each gap estimate, published by SEDA along with the gap estimates.

${ }^{14}$ This table reports SEDA's OLS estimates of test-score gaps, since they are used as dependent variables in the regressions. The SEDA researchers (Fahle et al. 2019) suggest using different measures for descriptive versus outcome-measure purposes. ("In general, the EB [Empirical Bayes] estimates should be used for descriptive purposes and as predictor variables on the right-hand side of a regression model; they are the estimates shown on the website (https://edopportunity.org). They should not be used as outcome variables in a regression model because they are shrunken estimates. Doing so may lead to biased parameter estimates in fitted regression models. The OLS estimates are appropriate for use as outcome variables in a regression model" [pp. 36-37].) Descriptively, the score gaps, levels, and patterns shown in Table 1 are very similar to those of the EB estimates. 
Delaware, District of Columbia, Florida, Georgia, Maryland, North Carolina, South Carolina, Virginia, and West Virginia) showing the largest average white-Black gap, the Pacific division (about 80 metro areas in Alaska, California, Hawaii, Oregon, and Washington) the largest white-Hispanic gap, and the New England division (almost 30 metros in Connecticut, Maine, Massachusetts, New Hampshire, Rhode Island, and Vermont) displaying the largest average test-score gap between students who are not economically disadvantaged and those who are, with the Pacific states a close second.

Regarding levels, New England metro areas, on average, show the highest average test-score levels on this national scale for all subgroups. At the low end, the East South Central division has the lowest average test scores for white students and Black students, while metro areas in the Pacific division have the lowest average scores for Hispanic students as well as the lowest average scores for economically disadvantaged students.

\section{B. School Quality, School Inputs, and School Finance}

State constitutions across the United States assign responsibility for "adequate" ("sound," "basic") and/or "equitable" public education to the state government. Most state governments delegate responsibility for managing and (partially) funding public (pre-)K-12 education to local governments. Most local governments use property taxation to fund the local public schools; the size of the property tax base relative to the cost of local education varies widely within states. Court cases in many states have established that, despite delegating operational responsibility, state governments remain ultimately responsible for the adequacy and/or equity of the public $\mathrm{K}-12$ education in the state. To achieve adequacy and/or equity, states distribute revenue to local school districts, typically in inverse proportion to the local districts' ability to raise revenue locally and proportional to enrollment size. This aid offsets some fraction of disparities among districts in ability to pay and may, in addition, target certain types of students thought to need additional resources.

\section{School Quality, School Inputs, and School Finance: Discussion}

The largest portion of state aid to local school districts is typically provided on a per-student basis through a "foundation," "power-equalizing," "flat grant," or "tiered" program. Foundation programs are the most widely used, and (in approximate terms) provide per-student aid to fill the gap between a state-determined foundation amount needed to educate local children and the amount of revenue local district resources might yield at a state-determined standard tax rate. District-power-equalizing (DPE) formulas promise state funds to make up the difference between the per-pupil amount the local district 
raises with its school tax rate and the per-pupil amount a state-defined (larger) tax base would yield at that tax rate, essentially matching all local funds at a rate inversely proportional to each district's local revenue-raising ability. Flat grant programs, as the name suggests, provide the same per-pupil amount to all districts. Tiered programs combine foundation and DPE aid. In most states, school aid is funded out of the state's general fund, hence representing some fraction of the full array of state revenue sources. In a few cases, including Vermont, the state levies a statewide property tax and then redistributes the revenue according to one of the above formula types.

In addition, some states include cost adjustments in their formulas. Key attributes on which states base such cost adjustments are student poverty, English language facility, and special education or disability status. A widely used form of cost adjustment employs student "weights" reflecting the additional cost associated with educating a student with a specific characteristic; aid is then allocated in proportion to weighted enrollment rather than unweighted enrollment. As noted earlier, a research literature describes how such costs and hence such weights can be estimated, but consensus is lacking on appropriate methods, and states vary considerably in the degree to which, if any, they adjust aid for cost differentials among districts.

In this context, school quality in a district or metro area will be a function of school spending in the area, where spending summarizes educational inputs. In addition, differences in quality among schools and districts within a metro area may reflect the attributes of the formula the state uses to allocate funds among school districts as well as the overall amount of state funding.

\section{School Quality, School Inputs, and School Finance: Data}

When trying to model student achievement or test scores, researchers have typically turned to measures of school inputs, especially per-pupil spending, as explanatory variables. Spending pays for the direct inputs - notably teachers and support staff-that contribute to student learning. The SEDA data set includes metropolitan area per-pupil spending, in total and for instructional purposes, averaged across districts in the metro area using student weights. The data also include per-pupil spending (total and instructional) in the average white, Black, Hispanic, free-lunch, non-free-lunch, economically disadvantaged, and not-disadvantaged student's district in each metro area. ${ }^{15}$ Higher average school spending is expected to be associated with smaller test-score gaps, because students with lower average

\footnotetext{
${ }^{15}$ These are "exposure" measures that weight each district's per-pupil spending by the district's fraction of metroarea Black (white, Hispanic, free-lunch, etc.) students, to generate a weighted average per-pupil spending figure for Black (white, Hispanic, free-lunch, etc.) students.
} 
test scores (racial minorities and low-income students) should benefit more, at the margin, from additional dollars. Furthermore, disparities in spending between the average minority or low-income student's district and the average white or higher-income student's district would be expected to exacerbate test-score gaps.

Several authors have compiled information on how states distribute aid to school districts. Deborah Verstegen (2011) provides a comprehensive listing of state-aid programs based on a 2010 survey, including categorizing the basic state-aid program in each state (foundation plan, flat grant, etc.) and treatment of special-education students, low-income students, and English-language learners, which might include weighting, categorical aid, or cost reimbursement. Hightower, Mitane, and Swanson (2010) also lay out the 50 states' methods for targeting aid as well as revenue sources and restrictions. EdBuild (see http://funded.edbuild.org/) similarly compiles current school-aid information for all 50 states, describing basic formula type, local revenue sources, and local requirements, as well as programs aimed at poverty, special education, English-language learners, gifted students, career and technical education, and adjustments for grade level, district sparsity, and small size.

In practice, many state school-aid programs have ceilings or floors, are not fully funded by the state legislature, apply "hold harmless" or "effort maintenance" restrictions, or otherwise diverge from the simple formulas outlined above. For these reasons, this analysis characterizes each state's school-aid formula using a summary measure of progressivity developed and published by the Rutgers Graduate School of Education/Albert Shanker Institute: School Finance Indicators Database. Baker, Di Carlo, and Weber $(2019,2020)$ create measures of the fairness or progressivity of a state's revenue distribution across districts. ${ }^{16}$ They define progressivity as the ratio of predicted (state) revenue for school districts with 30 percent of students living in poverty to predicted revenue for districts with 0 percent of students living in poverty; the predictions are based on descriptive regression estimates for each state, drawing on Baker et al. (2018). Based on actual state-specific aid-dollar patterns, the measure collapses information on formula type, use of weights, etc. The Rutgers authors argue that progressivity is a state (legislative) policy choice.

While the analysis focuses on the progressivity measure, I compare the progressivity results with results

\footnotetext{
${ }^{16}$ Because the progressivity measure shows an extreme value for Wyoming, I drop Wyoming metro areas and districts from the regression analysis. (For each state, I average Rutgers' predicted values for 2008, 2009, and 2010; in this form, the other state values fall between 0.7 and 7.6; Wyoming's value is 25.5.) Wyoming is also missing math and ELA data for grades 3 through 8 in three of the years from 2008/09 through 2015/16. This omission does not change the estimated coefficients on either progressivity or other variables to any noticeable degree.
} 
based on simpler characterizations of state school aid (for example, formula type and cost indicators such as poverty weights) at the end of the paper. In addition, I include a very simple measure of the amount of state aid, defined as the log of state revenue per student sent to all districts statewide.

That some metropolitan areas cross state lines complicates the measurement and interpretation of state-aid indicators in explaining metro-area test-score gaps. About 6 percent of the metro areas in the sample cross state lines (62 of 934 areas). I calculate a weighted average of "state-aid progressivity" (as well as other state variables) for each metro area, where the progressivity faced by each district in the metro area (school districts do not cross state lines) is averaged using the fraction of metro students in each district as weights. ${ }^{17}$

Except for when it's applied to these multistate metros, the progressivity measure is a state-level variable-one value for all the districts and metro areas in a state. To allow the effect of state aid to vary across areas within a state, the progressivity measure is interacted with the percentage of school-age children living in poverty in the average district in the metro area. ${ }^{18}$ Thus the "effect" of progressivity varies across metropolitan areas with the prevalence of poverty in the metro area's school districts. Metro areas with more poverty would receive more dollars from a more progressive aid distribution compared with the amount that would go to metro areas in the same state with less poverty. If that additional aid helps to increase student test scores in high-poverty districts, it is likely to reduce testscore gaps between students who are not economically disadvantaged and those who are in those metro areas to the degree that economically disadvantaged students are concentrated in high-poverty districts. And to the degree that minority students are concentrated in high-poverty school districts, it may similarly reduce racial test-score gaps. Recall, however, that LaFortune, Rothstein, and Schanzenbach (2018) find that the school-aid reforms of the 1990s and early 2000s raised spending and test scores in low-income districts relative to high-income districts, but did little to reduce gaps between low-income and high-income students, or between minority and white students. Hence the association between test-score gap-closing and more-progressive aid distributions is not a foregone conclusion.

For a high-poverty district in a state with a more progressive aid distribution, being on the receiving end

\footnotetext{
${ }^{17}$ An alternative is to assign multistate metros to one state, the one accounting for the greatest fraction of metro population. Another alternative is to drop multistate metros from the sample. In practice, the results are not sensitive to either of these changes, with both signs and significance virtually the same as in the preferred specification with metro average progressivity.

${ }^{18}$ These school-age poverty data at school-district geographies are reported by the U.S. Census Bureau, Small Area Income and Poverty Estimates.
} 
of poverty-focused higher per-student aid might encourage an emphasis on the neediest students and/or the district's lowest performing schools that disproportionately serve disadvantaged students. Aid to such districts might thereby reduce within-district test-score gaps between races or between economically disadvantaged students and advantaged students.

The exploration of state school aid is handicapped by the key progressivity variable varying only minimally across metros and districts within a state. While this reflects the very nature of state school aid, it presents an econometric challenge. Furthermore, Reardon, Kalogrides, and Shores (2018) note that

"there is considerable variation in white-Black and white-Hispanic achievement gaps across school districts and metropolitan areas. Yet most of this variation appears to be driven by local, rather than state-level, forces: almost 90 percent of the variation in district achievement gaps lies within states. Although average levels of academic performance vary substantially among states, district racial achievement gaps do not differ much, on average, among states, at least not in comparison to how much they differ within states. Local forces dominate state-level processes in shaping patterns of racial/ethnic academic achievement gaps" (p. 35).

That observation suggests that it will be difficult to establish relationships between state-level measures and test-score gaps.

\section{Segregation and Disparities in Parental and Community Characteristics}

Earlier research indicates that parental income and education are strongly positively associated with children's achievement, while children whose parents have low incomes or children living with single mothers do worse in school, on average. These outcome differences are usually attributed in part to the "educational enrichment" that higher-income, more educated parents are able to give their children, as discussed earlier. Single-parent families, by definition, have less potential parental time for interacting with children (reading to them, talking to them, helping them with homework). Parental poverty is associated with higher childhood stress, which can affect brain development, cognitive function, and subsequent academic success (see Nelson and Sheridan 2011).

Neighborhood and community characteristics are strongly linked to parental characteristics, partly because the former reflect a neighborhood aggregation of parental characteristics (plus the characteristics of non-parents in the neighborhood), and partly because parents choose a child's residential location. Parents with more resources are often able to choose communities that have better public amenities, such as parks. They are also better able to pay for such advantages through home 
prices and local property taxes than are parents with severely limited resources.

Some individual school districts and metropolitan areas engage in school choice programs that allow students to attend schools or districts not related to their residence location. The Boston area, for example, has long had the METCO program, which allows some minority students living in Boston to attend school in surrounding suburbs. Such programs loosen the link between the characteristics of the neighborhood or district of residence and those of the place where the student attends school.

As the simple education production function model presented earlier indicates, test-score gaps by race and income are expected to be a function of disparities in schools and other circumstances between children of different races or socio-economic statuses. Children in a metropolitan area or school district can face different school quality or different neighborhood circumstances if they go to different schools within the district or live in different neighborhoods in the district, or if school quality and neighborhood characteristics vary across districts. Reardon, Kalogrides, and Shores (2018) diagram a model in which racial family socioeconomic disparities interact with residential segregation and school segregation (and local education policies) to produce racial achievement disparities; one can think similarly about income disparities and residential and school segregation by income. Those authors write, "The strongest correlates of achievement gaps are local racial/ethnic differences in parental income, local average parental education levels, and patterns of racial/ethnic segregation, consistent with a theoretical model in which family socioeconomic factors affect educational opportunity partly though residential and school segregation patterns" (p. 1). The current analysis is expected to find very similar relationships between racial and income segregation and test-score gaps. The Stanford authors have not yet published work analyzing test-score gaps between students who are economically disadvantaged and those who are not, so the results below represent an extension of their findings.

Another frequently analyzed aspect of school quality is peer effects: Each student's educational success is hypothesized to depend not only on educational inputs at the school and district levels, but also on things learned from classmates. This study has no direct measures of peer quality. However, to the degree that white, Black, Hispanic, economically disadvantaged, and not-disadvantaged students attend the same schools, they are likely to have similar peers; to the degree that different groups are isolated across schools or among districts, they will have peers that are different from each other's. Hence the estimated coefficients on the school and district segregation measures outlined below will include peer influences, but also other results of segregation or shared experiences. 


\section{Metro/District/Community Characteristics: Data}

Metro-area and district characteristics are based on two data sources. One source reports on school children in the district and another on parents of public-school children.

Data describing selected characteristics of the children attending school in public-school districts nationwide are available from the National Center for Education Statistics (NCES). I aggregated data for school year 2009/10 across all public schools serving children in any grade third through eighth in each district. The information includes the racial and ethnic mix of children in schools (percentage who are Black, percentage who are Hispanic) as well as reporting on child poverty as measured by eligibility for the federal free lunch program. ${ }^{19}$ SEDA data sets similarly report district and metro-area measures based on school-level information on children's racial, ethnic, and socioeconomic mix; these district and metro-area data refer to the full SEDA period, 2008/09 through 2015/16.

Information on parental characteristics at the district level were collected from a special compilation of the five-year (2006 through 2010) American Community Survey data for school-district geographies (ACS-ED or EDGE) reporting on "parents of public-school enrolled children" by race. ${ }^{20}$ SEDA also compiled and published these data, including metro-area percentage and district percentage of parents who are living in poverty, percentage of parents who are unemployed, and percentage of parents who have a bachelor's degree or more.

\section{Segregation and Disparities: Data}

The segregation and disparity measures are based on the same data sources as the district and metro characteristics. School segregation measures look across schools within each school district or across districts within each metro area; parental disparities compare characteristics of parents of different races in each metro area.

Segregation measures are based on exposure differences among children of different races or economic statuses across schools within districts or across districts within metro areas. Thus, Black-white school segregation is defined as the percentage of students who are Black in the average Black student's school minus the percentage who are Black in the average white student's school; Black-white district

\footnotetext{
${ }^{19}$ Children are eligible for free school lunches if their family's income is below 130 percent of the federal poverty line.

${ }^{20}$ The U.S. Census Bureau and U.S. Department of Education compile data for school district geographies in every five-year ACS, but the special 2006-2010 compilation excerpted information for parents of public-school-enrolled children.
} 
segregation is defined the same way, substituting "district" for "school" and looking across districts within a metro area. Hispanic-white school segregation and district segregation are defined in a parallel way. Similarly, poverty segregation is defined as the percentage of students who are in the free-lunch program in the average low-income (free-lunch) student's school or district minus the percentage who are in the free-lunch program in the average higher-income (non-free-lunch) student's school or district. Continuing in this way, Black-white poverty segregation is defined as the percentage of students who are low-income (eligible for free school lunches) in the average Black student's school or district minus the percentage who are low-income in the average white student's school or district; the same calculation is done for Hispanic-white poverty segregation in a school or in a district.

As noted above, the ACS reports data for parents of public-school-enrolled children by race. While not all parental characteristics are reported by race, I include measures of Black-white and Hispanic-white differences in percentage of parents who are college educated, percentage who are unemployed, and percentage who are living in poverty.

Table 2 reports averages of selected school and district segregation measures across metropolitan areas. The "within-district" figures refer to within-district segregation across schools averaged across districts in each metro area. Thus, column 2 in the first panel starts with a measure of school segregation within each school district: the difference between the percentage of students who are Black in the average Black student's school and the percentage who are Black in the average white student's school. For each metro area, those difference measures are averaged across all the districts in the metro area, weighting by district enrollment. The "between-district" data report differences among districts in the metro area. Thus, column 3 in the first panel reports the difference between the percentage of students who are Black in the average Black student's district and percentage who are Black in the average white student's district. Columns 4 and 5 of the upper two panels report average poverty segregation by race, that is, racial differences in exposure to low-income students, within districts and across districts in the average metro area, while columns 2 and 3 of the bottom panel report poverty segregation (not by race), that is, differences between low-income and higher-income students in exposure to low-income (free-lunch) students, within districts and across districts.

The "All" row in each panel reports simple averages and the "Weighted All" row reports weighted averages across all metropolitan areas in each of the test-score-gap samples. For the weighted averages, the weights are the same as in Table 1, reflecting the reliability of the metro-area test-score-gap estimates. On average, racial segregation across districts in metro areas is greater than racial 
segregation within districts. Similarly, poverty segregation by race is higher across districts than within districts. By contrast, poverty segregation (not by race- bottom panel) is somewhat greater, on average, within districts than between them for the average metro area. Hispanic-white segregation is generally lower than Black-white segregation.

These segregation patterns differ considerably among the nine census divisions. The New England and Middle Atlantic divisions (almost 70 metro areas in New Jersey, New York, and Pennsylvania in the latter division) show high levels of racial and poverty segregation between districts and lower levels among schools within districts. This pattern reflects, in part, the fact that school districts in these regions are relatively small, and that there is a correspondingly large number of districts within the average metro area (see the right-most column of the bottom panel). The South Atlantic states, by contrast, show the highest levels of within-district Black-white school segregation and within-district poverty segregation; note that there are only four districts per metro area in that region, on average. The Mountain division (65 to 85 metro areas in Arizona, Colorado, Idaho, Montana, Nevada, New Mexico, Utah, and Wyoming) and the Pacific division display high levels of within-district school segregation of Hispanic students and low-income students.

\section{Regression Specification and Results}

As described in the preceding sections, test-score gaps between metropolitan-area or district students of different races or students of different economic statuses are expected to reflect school spending (more spending should be associated with smaller gaps), the per-student dollar amount of state school funding (gaps should be smaller where there is more state money in general), and the progressivity of state-aid allocation across districts (more progressive state funding is expected to be negatively associated with gaps in areas with more poverty). Test-score gaps will also be higher where school segregation by race and by poverty is higher, both within school districts and across districts in the metropolitan area, and also where parental disparity measures by race are greater. These hypotheses suggest the following estimating equation for test-score gaps between white and Black students observed in a metropolitan area:

$$
G_{m w B}=a_{0}+a_{1} Q_{m}+a_{2} S_{m w B}+a_{3} P_{m w B}
$$

Where

- $\mathrm{G}_{\mathrm{mwB}}$ represents the gap between test scores for whites and Blacks in metro area $m$ 
- $\mathrm{Q}_{\mathrm{m}}$ is a vector of spending-based school-quality measures, including per-pupil spending, the perpupil level of state aid to schools, and the progressivity of state aid to schools. The progressivity measure is interacted with a measure of school-district poverty in the metro area to capture variation in the manifestation of progressivity among metro areas in a state.

- $\mathrm{S}_{\mathrm{mwB}}$ is a vector of measures of segregation (racial segregation and poverty segregation) between Blacks and whites, both within school districts and across districts in the metropolitan area.

- And $P_{m w B}$ includes indicators of parental disparities between Blacks and whites in the metropolitan area.

Parallel equations can be estimated for test-score gaps between white and Hispanic students and between not-disadvantaged and economically disadvantaged students.

Because several explanatory variables are observed at the state level and because the accountability tests underlying SEDA's test-score-gap estimates differ across states, I cluster errors by state. Clustering is appropriate because these two characteristics of the data suggest that district or metro observations within states are not independent. Because the SEDA test-score gaps (the dependent variables) are estimated, I account for the quality of the estimates (as Fahle et al. 2019 suggest, p. 37) by weighting observations inversely to the square of the reported standard error for each test-score gap.

Appendix Table A1 reports summary statistics for the metropolitan-area regression variables, and Tables $\mathrm{A} 2$ and $\mathrm{A} 3$ report sources for metro-area and district data.

As reported earlier in the discussion of Table 1, test-score gaps are measured as the metro-area average difference between white students' test scores and minority students' test scores (white minus minority); as such, the gaps are bigger positive numbers when minorities are performing less well relative to whites. The explanatory measures of minority-white disparities or segregation report the difference between the average characteristics or exposure of minority students (or parents) and the average characteristics or exposure of white students (or parents) (Black minus white or Hispanic minus white)-exposure to poverty in school, exposure to minority students, difference in the percentage of parents who are unemployed. Because minority students generally face higher levels of these adverse characteristics and the calculation is minority minus white, these differences are usually positive, and where they are bigger-more segregation, more exposure to higher school poverty rates compared with whites, higher percentage of minority parents who are unemployed, etc.-test-score gaps are expected 
to be bigger.

By contrast, a few of the disparities or differences relate to attributes that provide favorable exposure; these include the percentage of parents who are college educated and racial differences in per-pupil spending. Because these measures are also calculated as minority characteristic minus white, where these variable values are higher (the minority-white difference is less negative), test-score gaps are expected to be smaller. This expected negative coefficient is the opposite sign of the expected positive coefficient on disparities in disadvantageous characteristics described in the preceding paragraph.

\section{A. Explaining Metropolitan-Area Test-Score Gaps}

Metropolitan-area test-score gaps measure the difference between the test scores for white and Black students or white and Hispanic students or not-disadvantaged and disadvantaged students in a metropolitan area. As such, they reflect differences in test scores within individual districts and across districts within the metro area. As Table 2 displays, overall metro segregation measures can be separated into indicators of segregation within districts and segregation across districts; these separate indicators are included in the metro regressions to help understand the test-score gaps.

In broad brush, the regression results in Tables 3 and 4 suggest a negative association between more "redistributive" state school aid and racial test-score gaps in metro areas with more high-poverty districts. Measures of minority-white poverty segregation and disparities also play a significant role (with the expected signs described above) in test-score gaps. Table 5 shows broadly similar results for testscore gaps between students who are not economically disadvantaged and those who are.

In all three tables of metro-gap results, the first two columns include a broader list of explanatory variables compared with those in columns 3 and 4 , which eliminate explanatory variables whose estimated coefficients are generally indistinguishable from zero (in a statistical sense). The parentaldisparities measures are available for a smaller set of metro areas compared with the other explanatory variables; columns 2 and 4 include those disparities and have considerably smaller sample sizes than columns 1 and 3, which otherwise include the same variables.

\section{State Aid and School Spending}

The amount of statewide per-student school aid and metro-average per-pupil instructional spending are unrelated to racial and economic test-score gaps. These variables are dropped in the leaner specifications reported in columns 3 and 4 . 
Test-score gaps are smaller in metro areas where the state revenue distribution is more progressive and average district poverty is higher. ${ }^{21}$ As noted above, the equations include the state-aid progressivity measure (with a positive estimated coefficient) and that measure interacted with the fraction of students living in poverty in the average district in the metro area (which obtains a negative estimated coefficient). With opposite signs on the two measures that move together by definition, it is useful to calculate the size of their net effects. Evaluated at the mean values of these two variables, the sum is negative. Using the estimates in column 1 of Table 3, a metro area with average poverty but onestandard-deviation above-average progressivity would see about 7 points smaller white-Black test-score gaps; a metro area with one-standard-deviation above-mean metro-average poverty (with state-aid progressivity unchanged) would see about 8 points smaller white-Black test-score gaps. Raising both average district poverty and state-aid progressivity by one standard deviation each is associated with a white-Black test-score gap that is about 14 points (0.14 standard deviation) smaller. The estimated coefficients in column 3 yield a similar "impact" estimate. A 14-point difference represents about onefifth of the average metro white-Black test-score gap in the regression sample (as reported in the "weighted all" row of the top panel of Table 1). Recall that, arguing from causal estimates, Lafortune, Rothstein, and Schanzenbach (2018) find that "ten years after a reform, relative achievement of students in low-income districts has risen by roughly 0.1 standard deviation, approximately one-fifth of the baseline gap between high- and low-income districts" (p. 4)-a similar magnitude.

The estimated coefficients vary across the specifications (columns), being notably weaker in the smaller samples that include parental disparities (columns 2 and 4). In addition, the progressivity coefficients are generally smaller in the white-Hispanic equations. However, because the average white-Hispanic testscore gap is smaller (recall Table 1), the fraction of the average gap represented by estimated coefficients multiplied by standard deviation increases in both average poverty and progressivity is equivalent to about one-fifth of the average white-Hispanic test-score gap, similar to the white-Black gap results.

The estimated coefficients on progressivity are also smaller in the equations explaining test-score gaps between students who are not economically disadvantaged and those who are, yielding somewhat smaller, but still negative, marginal effects of progressivity and district-average poverty on metro-area

\footnotetext{
${ }^{21}$ As noted above, the specification includes progressivity (prog) and progressivity multiplied by metro-average school-age poverty (pov*prog), each of which obtains an estimated coefficient $\left(a_{1}\right.$ and $\left.a_{2}\right): \ldots+a_{1}{ }^{*} p r o g+$ $a_{2} *$ pov*prog). The estimates indicate that $a_{1}$ is positive and $a_{2}$ is negative. Hence the full coefficient on progressivity $\left(=\left(a_{1}+a_{2} *\right.\right.$ pov $\left.)\right)$ varies inversely with metro-average school-age poverty.
} 
test-score gaps between not disadvantaged and economically disadvantaged children in columns 1 and 2 of Table 5, and more substantial impacts in the estimates reported in columns 3 and 4 . For example, the coefficient estimates in column 3 imply that a metro area with one-standard-deviation aboveaverage progressivity and one-standard-deviation above-average poverty would have a 0.13-standarddeviation smaller test-score gap than an average metro area, equivalent to about one-fifth of the average gap between not disadvantaged students and economically disadvantaged students.

Since progressivity refers to how redistributive the formula is toward high-poverty districts, these effects are not surprising in that, as hypothesized earlier, more redistributive aid should improve the scores for lower performing students by providing more state funds to the highest-poverty districts in high-poverty metro areas. Even though these estimated progressivity effects seem plausible, most of the earlier research on state aid fails to find similar effects on test-score gaps. As noted above, the most widely cited aid-reform studies, notably Jackson, Johnson, and Persico (2016), tend to find positive effects on various outcomes (school completion, adult wages, and adult poverty), but not test scores. Lafortune, Rothstein, and Schanzenbach (2018) report positive effects on test scores in low-income districts as a result of more aid being channeled there (as cited three paragraphs above), but no effect on racial or socioeconomic test-score gaps, which, they argue, is because low-income and minority students within states are not highly concentrated in low-income districts (where the reforms they analyze raised spending). Here I find substantial (net) gap-reducing coefficients on progressivity where district poverty is high for white-Black gaps, white-Hispanic gaps, and gaps between students who are not disadvantaged and economically disadvantaged students. That said, the cross-sectional approach makes strict causal inference impossible. Like those from the earlier (pre-quasi-experimental) school-finance research summarized by Jackson (2018), these results establish a potentially meaningful net negative relationship between the progressivity of state school aid and racial and economic test-score gaps in metro areas with greater district poverty. However, it remains for better data with some exogenous shifters or instruments to establish a causal link between state school-aid characteristics and test-score gaps. $^{22}$

\section{Racial and Economic Segregation and Other School-Related Disparities}

Greater racial segregation, especially within districts, is associated with larger metro-area test-score gaps between not disadvantaged and economically disadvantaged students, but segregation by race has

\footnotetext{
${ }^{22}$ As noted above, the earlier "plausibly causal" studies rely on court-imposed finance reforms.
} 
very little direct effect on racial test-score gaps. ${ }^{23}$ By contrast, poverty segregation by race (across schools within districts and between districts) is strongly associated with racial test-score gaps; put another way, where minority students are in schools or districts with much greater fractions of lowincome students compared with the schools or districts of white students, test-score gaps between the races are larger. This finding echoes those of Reardon (2016) and Reardon, Weathers, et al. (2019), who find that racial test-score gaps are strongly associated with high concentrations of minority students in high-poverty schools. Indeed, the estimated coefficients here are similar in magnitude to Reardon's (2016): ${ }^{24}$ A 20 percentage point Black-white difference in exposure to low-income students (with 8 points of within-district Black-white poverty segregation and 12 points of between-district Black-white poverty segregation, reflecting the means in Table 2) corresponds to a test-score gap of 0.10 to 0.22 standard deviation (depending on which column's estimates are used) or roughly one-seventh to onethird of the average white-Black test-score gap. ${ }^{25}$ For the white-Hispanic gap equations, the average between-district racial poverty segregation is somewhat smaller (Table 2), and so is the average racial test-score gap; the range of coefficient estimates on Hispanic-white poverty segregation in Table 4 applied to average Hispanic-white poverty segregation corresponds to a test-score gap amounting to between one-sixth and one-third of the average white-Hispanic test-score gap.

Similarly, greater poverty segregation, both within and between districts, increases test-score gaps between students who are not economically disadvantaged and those who are. That is, in metro areas where low-income students are more segregated among schools or among districts, economically disadvantaged students perform less well relative to non-disadvantaged students. Within school districts, the schools that low-income students attend have about 9 percentage points higher fractions of low-income compared with the schools higher-income students attend; between districts, poverty

\footnotetext{
${ }^{23}$ While the estimated coefficients on black-white segregation between districts are negative and significantly different from zero in columns 1 and 2 of Table 3, they are smaller than the positive coefficients on racial differences in exposure to poverty in those equations. Furthermore, in the absence of the poverty exposure variables, the between-district racial segregation measure obtains a positive coefficient that is significantly different from zero (results not shown). Thus, the negative relationship-suggesting segregation reduces test-score gaps-occurs only when controlling for poverty segregation by race.

${ }^{24}$ Reardon (2016) also uses pooled data (at that point, only school years 2008/09 through 2011/12 were available) for metro-area test-score gaps. The 2016 study is more comparable to the current one than to Reardon, Weathers, et al. (2019) because the latter focuses on third-grade gaps (not pooled over grades) as well as growth in the gap across grades.

${ }^{25}$ As noted earlier, Reardon (2016) reports that his coefficients imply that a 20 percentage point racial difference in exposure to poverty (Black-white or Hispanic-white)-the average metro-area difference in his samplecorresponds to an achievement gap of 0.12 to 0.15 standard deviation, or "roughly one-fifth of the average racial achievement gap" (p. 20).
} 
segregation averages about 8 percentage points (Table 2). These disparities multiplied by the coefficient estimates in Table 5 correspond to 0.10 to 0.14 standard deviation, or approximately one-sixth to onefifth of the average test-score gap between students who are not economically disadvantaged and those who are.

The other metro-area disparity measures reported by SEDA-focusing on differences in student-teacher ratios (across schools) or instructional spending (across districts) by race or free-lunch status-have no significant relationships with test-score gaps. These latter variables plus the racial-segregation indicators are dropped, while the poverty-segregation variables noted above are carried over to the leaner specifications in columns 3 and 4.

\section{Metropolitan Area and Parental Characteristics}

White-Hispanic test-score gaps are somewhat larger in metro areas with a higher representation of Hispanic students; the same does not seem to be the case for metro concentrations of Black students or low-income students with respect to test-score gaps between white and Black students or nondisadvantaged and disadvantaged students.

Columns 2 and 4 of Tables 3, 4, and 5 include additional variables measuring parental characteristics in the metropolitan area. Because they are based on the ACS, these data are reported by SEDA for fewer metro areas; note that the sample size is markedly smaller in columns 2 and 4. In Tables 3 and 4, racial differences in unemployment rates and the percentage of parents with a bachelor's degree or more are significantly related to racial test-score gaps, and with the expected signs. In metro areas where unemployment rates for minority parents are greater than they are for white parents, test-score gaps are larger, but only to a limited degree. For example, a metro area where minority parents' unemployment is 2 percentage points higher than unemployment for white parents (the standard deviation among metros in the sample) would display a 0.03-standard-deviation larger test-score gap, a small fraction of the average test-score gap between white and Black students or white and Hispanic students. In addition, in metro areas where white public-school parents are college educated to a greater extent than minority parents, test-score gaps are higher, and here the apparent importance is larger, since the BA-plus differences vary more among metro areas. ${ }^{26}$ For example, a metro area where

\footnotetext{
${ }^{26}$ Recall the discussion of signs on "positive" attributes in the previous section. The negative estimated coefficient on the difference between the percentage of minority parents with a BA or more and the percentage of white parents with a BA or more (minority percent minus white percent) indicates that in metro areas where the minority-white gap in BA attainment is larger (in absolute value-more negative), the test-score gap is larger.
} 
BA-plus attainment is 7 percentage points greater among white parents relative to minority parents (approximately the standard deviation among metros in the sample) would show a roughly 0.1standard-deviation larger test-score gap between white children and minority children. ${ }^{27}$

In Table 5, greater racial differences in parental poverty are associated with larger test-score gaps between not disadvantaged and economically disadvantaged students. However, these effects are small in magnitude, with a one- standard-deviation higher poverty gap between Black and white parents and between Hispanic and white parents associated with a 0.05-standard-deviation larger socioeconomic test-score gap.

\section{B. Within-District Test-Score Gaps}

As noted above, metropolitan area test-score gaps reflect gaps between students within school districts and among districts within each metro area. To further foster understanding of relationships within and between districts, Table 6 reports results from running similar regressions explaining racial and socioeconomic test-score gaps, where the observations are for school districts, not metropolitan areas (most of which include multiple districts). Note that the school districts analyzed are all districts with available data, not only districts within metropolitan areas. Overall, the results are similar to those for metro areas, indicating higher test-score gaps where segregation is greater and where racial differences in parental characteristics are more disadvantageous to minority students.

\section{State Aid and School Spending}

Statewide per-student school aid has no relationship with test-score gaps in school districts. In most cases, district school spending per pupil similarly has no relationship, but when that is not the case, the relationship is positive, counterintuitively suggesting that more spending is associated with larger testscore gaps. ${ }^{28}$

The progressivity of the state's school-aid distribution is associated with smaller test-score gaps in highpoverty districts. In these equations (similar to the metro-area equations), the progressivity measure is included alone (same state value for all districts in each state) and also multiplied by the fraction of the district's school-age-children who are living in poverty. The latter interaction variable consistently

\footnotetext{
27 The parental unemployment gap between Black and white parents is larger, on average, than the parental unemployment gap between Hispanic and white parents; by contrast, the difference between Hispanic and white parents in attainment of a BA or higher is greater, on average, than the difference between Black and white parents.

${ }^{28}$ The simple correlations between spending and test-score gaps are all indistinguishable from zero (less than 0.1).
} 
obtains a negative coefficient that is significantly different from zero. ${ }^{29}$ This estimate might suggest that more-progressive state-aid formulas, which by definition send more dollars to high-poverty districts, lead those districts to focus educational attention on minority or economically disadvantaged students and/or the schools they attend, raising their scores. But the result is a cross-sectional one, so we can infer only descriptively that, controlling for school segregation and parental disparities, high-poverty districts in states with more-progressive formulas have gaps that are smaller than those of lowerpoverty districts in those states or smaller than those of districts with similar poverty levels in states with less progressive distributions.

\section{School Segregation}

The findings regarding school segregation within districts are very similar to those for metropolitan area within- and between-district segregation reported in the preceding section. Racial segregation of schools increases test-score gaps between students who are not economically disadvantaged and those who are, but not the test-score gaps between races. ${ }^{30}$

Racial differences in exposure to low-income students in school are associated with larger racial testscore gaps at the school-district level. The magnitudes of these coefficient estimates on racial poverty segregation in columns 1 through 4 are similar to those on the corresponding variables (average withindistrict racial poverty segregation) in Tables 3 and 4, depending on specification. They are also of similar magnitude to the coefficients reported by Reardon, Weathers, et al. (2019), who obtain coefficient estimates of 0.9 to 1.0 on variables measuring racial differences in exposure to low-income schoolmates in their examination of district-level achievement gaps. ${ }^{31}$

Segregation of low-income students among schools is associated with larger socioeconomic test-score gaps at the district level as well. Poverty segregation of 8 or 9 percentage points (the mean and standard deviation of the district poverty segregation measure) is associated with a 0.05 - to 0.07 -standarddeviation greater test-score gap between students who are not economically disadvantaged and those

\footnotetext{
${ }^{29}$ Evaluated at the means of progressivity and progressivity interacted with district poverty, the net effect is negative. Adding one standard deviation of progressivity or poverty narrows white-Black test-score gaps, for example, by 8 to 9 points, using the regression estimates shown in column 1.

${ }^{30}$ Black-white school segregation is associated with smaller white-Black test-score gaps when controlling for Blackwhite poverty segregation. However, similar to the result noted in the earlier footnote discussing the metro-area white-Black test-score gap regressions, the estimated coefficient on racial school segregation is positive and significantly different from zero when differential school poverty exposure by race is not included in the district white-Black gap regressions of Table 6 (results not shown).

${ }^{31}$ These coefficient estimates are reported in the top panel of Tables 5 and 6 in Reardon, Weathers, et al. (2019).
} 
who are.

\section{District Characteristics and Parental Disparities}

For racial test-score gaps, the estimated coefficient on the fraction of students who are minorities is either statistically indistinguishable from zero or positive. Socioeconomic test-score gaps, by contrast, are negatively associated with the fraction of students who receive free or reduced-price lunch, a counterintuitive result.

As in the metro-area regressions, the measures of parental disparities are available for fewer districts than the other included variables, although this difference is marked only for the economicdisadvantage-gap equations. Racial disparities in parental college education and unemployment have significant associations with racial test-score gaps: In districts where white parents have a greater degree of college attainment than Black or Hispanic parents or have lower unemployment than Black or Hispanic parents, the disparity in their children's test scores is larger. Furthermore, racial disparities in parental poverty in a school district are associated with larger test-score gaps between children who are not economically disadvantaged and those who are.

\section{Relationships between Test-Score Gaps in Districts and Metropolitan Areas}

Test-score gaps for metropolitan areas reflect both within-district and between-district disparities in test scores. For this reason, the equations for metro-area test-score gaps include measures of both withindistrict and between-district segregation by race or income or race-by-income (racial poverty segregation). Tables 3 through 5 generally show estimated coefficients of similar magnitude for the within-district (average over districts in metro area) and between-district measures of each type. As Table 2 makes clear, however, there is considerable variation among metropolitan areas in the extent of these two types of segregation.

When the metro-area average within-district test-score gap is included as an explanatory variable in the three metro-area-gap equations, the results indicate-not surprisingly-that district-level gaps represent a very important element in metro-area gaps. ${ }^{32}$ Furthermore, between-district measures of poverty segregation (overall or by race) are significantly associated with metro-area test-score gaps by race or economic disadvantage, even when the estimating equation controls for the average district's

\footnotetext{
32 These equations were estimated with two-stage least-squares, treating the average district-level gap as an endogenous variable and using the within-district measures of segregation as instruments (results not shown).
} 
test-score gap.

\section{What Contributes to Progressivity of School Aid? Exploring State Aid Attributes}

The analysis reported above suggests that the manner in which states distribute aid for education may influence the size of test-score gaps between races and between students who are not economically disadvantaged and those who are. In particular, the more "progressive" the distribution, the smaller the test-score gaps in metro areas with more high-poverty districts and in high-poverty districts. Recall that the measure of state school-aid progressivity developed by Bruce Baker and others for Rutgers' School Finance Indicators Database reports, for each state, the ratio of predicted state revenue per pupil going to a school district where 30 percent of students live in poverty to that of a district where 0 percent of students live in poverty, with the predictions based on state-by-year-specific regression models.

As noted earlier, state school-aid formulas vary widely across the states, both in design and implementation. Looking across the states, only a few specific formula elements are associated with the summary measure of progressivity: Progressivity is higher in states that weight students living in poverty more heavily than higher-income students in their formula and in states that include weights for bilingual students (English-language learners, or ELL students) in their formulas. ${ }^{33}$ Revenue limitations are also associated with progressivity - negatively. That is, states restricted by revenue limitations have less-progressive school-aid funding, on average, compared with unrestricted states. ${ }^{34}$ It may be that restricted states are more constrained in attempting to tilt the school-aid distribution toward highpoverty districts.

If these state-aid characteristics are included in the metro-gap regressions in place of the progressivity measure-on their own (same value statewide) and interacted with average district poverty in the metro area, as the progressivity measure is-the results are similar to those for progressivity.

Specifically, the aid characteristic obtains a positive coefficient, and the interaction term obtains a larger (in absolute value) negative coefficient. In many cases, the estimated negative coefficient is significantly

\footnotetext{
${ }^{33}$ This statement is based on Hightower, Mikane, and Swanson's (2010) characterization of state school-aid formulas. Both of these indicators exceed a 5 percent threshold for significant difference of means (of progressivity) in a two-sided t-test. The authors also report whether states use weights for disability, grade level, career and technical, and academically at-risk students; none of these weighting systems are associated with school-aid progressivity. Also, using a foundation formula is not associated with progressivity.

${ }^{34}$ This statement is based on a 5 percent threshold for significant difference of means (of progressivity) in a twosided t-test using Rueben, Randall, and Boddupalli's (2018) characterization of budget limitations across states. Their measures of expenditure limitations, by contrast, are not associated with progressivity.
} 
different from zero; in some cases, the positive coefficient is also significantly different from zero. With an inverted version of the revenue limitation measure to indicate the state is not subject to revenue limits, those results are similar as well.

All three of these variables are zero-one indicators, unlike the continuous progressivity measure. To evaluate possible "impact" size, I calculate the combined coefficient-times-value for a change from zero to one in the indicator (for example, state uses poverty weights) and, for a state with that type of aidweighting (or lack of revenue limits) - that is, with the indicator set to one, the coefficient times a standard deviation increase in metro poverty. These effects are negative on net, although generally smaller than those outlined above for standard deviation increases in progressivity and poverty.

\section{Conclusion and Discussion}

During a time of increased focus on inequality, both racial and economic, reducing disparities in $\mathrm{K}-12$ educational success seems especially important. Equal educational opportunity is a key foundation for a more equitable society.

This research confirms a very strong link between test-score disparities by race or by economic disadvantage and poverty segregation along the same dimensions. This pattern holds for individual school districts' test-score gaps and for metropolitan-area test-score gaps. In the latter case, segregation matters both across schools within districts and across districts within the metropolitan area. Advocates of equal opportunity should continue to press for reductions in barriers to residential location choice both among districts and within districts. In districts (such as Boston) where elementary school assignment is not based entirely on residential location, the school-assignment algorithms should be examined for unequal impact on minority students and on low-income students. If disadvantaged and non-disadvantaged students and minority and white students go to the same schools, the education they receive is more likely to be similar than if they attend different schools.

Parental disparities by race-in educational attainment and joblessness-are also associated with racial test-score gaps, while parental differences in poverty by race are related to gaps between test scores for economically disadvantaged and non-disadvantaged students. Such gaps are not likely to shrink within a generation, so states and districts may need to address their effects with compensatory extra educational efforts, for example, in high-unemployment areas.

Another key factor associated with test-score gaps is the progressivity of the state distribution of school 
aid, measured in terms of the degree to which the state provides more aid per pupil to high-poverty districts. As noted earlier, states have diverse goals in distributing aid to local school districts.

Nonetheless, a key reason for state aid in all states is to reduce local-public-school dependence on local sources of revenue, the yield or value of which typically varies widely from district to district. That is, in providing funds to local school districts, states have attempted to offset local tax-base or wealth disparities and equalize resources, albeit among other goals. Many states also send more per-pupil aid to districts educating higher-cost students, particularly students from families living in poverty. States that provide more aid to high-poverty districts than to low-poverty districts have lower racial and socioeconomic test-score gaps in high-poverty districts and in the metro areas in which high-poverty districts are concentrated. Whether this relationship is causal or not, progressive aid distributions are a worthwhile goal for states to continue to pursue, both to offset inequality in district resources and to reduce cost disparities. And if the relationship were causal, a greater emphasis on state-aid progressivity would contribute to more equal educational opportunity across races and income groups. 


\section{References}

Baker, Bruce D., Matthew Di Carlo, and Mark Weber. 2019. "The Adequacy and Fairness of State School Finance Systems: Findings from the School Finance Indicators Database." First Edition. Published by the Albert Shanker Institute and Rutgers University Graduate School of Education.

Baker, Bruce D., Matthew Di Carlo, and Mark Weber. 2020. "The Adequacy and Fairness of State School Finance Systems: Key Findings from the School Finance Indicators Database." Second Edition. Published by the Albert Shanker Institute and Rutgers University Graduate School of Education.

Baker, Bruce D., Matthew Di Carlo, Ajay Srikanth, and Mark A. Weber. 2019. Rutgers Graduate School of Education/Albert Shanker Institute: School Finance Indicators Database. Retrieved from: http://www.schoolfinancedata.org.

Baker, Bruce D., Danielle Farrie, and David G. Sciarra. 2016. "Mind the Gap: 20 Years of Progress and Retrenchment in School Funding and Achievement Gaps." Policy Information Report and Educational Testing Service Research Report No. RR-16-15. http://dx.doi.org/10.1002/ets2.12098.

Baker, Bruce D., Mark Weber, Ajay Srikanth, Robert Kim, and Michael Atzbi. 2018. "The Real Shame of the Nation: The Causes and Consequences of Interstate Inequity in Public School Investments." Rutgers University Graduate School of Education and Education Law Center.

Barton, Paul E., and Richard J. Coley. 2010. "The Black-White Achievement Gap: When Progress Stopped." Educational Testing Service Policy Information Report. ED511548.

Burdick-Will, Julia, Jens Ludwig, Stephen W. Raudenbush, Robert J. Sampson, Lisa Sanbonmatsu, and Patrick Sharkey. 2011. "Converging Evidence for Neighborhood Effects on Children's Test Scores: An Experimental, Quasi-experimental, and Observational Comparison." In Whither Opportunity: Rising Inequality, Schools, and Children's Life Chances, ed. Greg J. Duncan and Richard J. Murnane, chapter 12. New York, NY: Russell Sage Foundation.

Card, David, and Jesse Rothstein. 2007. "Racial Segregation and the Black-White Test Score Gap." Journal of Public Economics 91: 2158-2184.

Chetty, Raj, Nathaniel Hendren, and Lawrence Katz. 2016. "The Effects of Exposure to Better Neighborhoods on Children: New Evidence from the Moving to Opportunity Project." American Economic Review 106(4): 855-902.

Cullen, Julie Berry, and Susanna Loeb. 2004. "School Finance Reform in Michigan: Evaluating Proposal A." In Helping Children Left Behind: State Aid and the Pursuit of Educational Equity, ed. John Yinger, chapter 7. Cambridge, MA: MIT Press.

Downes, Thomas. 2004. "School Finance Reform and School Quality: Lessons from Vermont." In Helping Children Left Behind: State Aid and the Pursuit of Educational Equity, ed. John Yinger, chapter 7. Cambridge, MA: MIT Press.

Duncombe, William D., Anna Lukemeyer, and John Yinger. 2004. "Education Finance Reform in New York: Calculating the Cost of a Sound Basic Education 'in New York City.'" Center for Policy Research, Syracuse University. Policy Brief: No. 28/2004. 
Fahle, Erin M., Benjamin R. Shear, Demetra Kalogrides, Sean F. Reardon, Belen Chavez, and Andrew D. Ho. 2019. Stanford Education Data Archive: Technical Documentation (Version 3.0). Retrieved from http://purl.stanford.edu/db586ns4974.

Flanagan, Ann E., and Sheila E. Murray. 2004. "A Decade of Reform: The Impact of School Reform in Kentucky." In Helping Children Left Behind: State Aid and the Pursuit of Educational Equity, ed. John Yinger, chapter 6. Cambridge, MA: MIT Press.

Hanushek, Eric A., Paul E. Peterson, Laura M. Talpey, and Ludger Woessmann. 2019. "The Unwavering SES Achievement Gap: Trends in U.S. Student Performance.” NBER Working Paper No. 25648.

Hightower, Amy M., Hajime Mitani, and Christopher B. Swanson. 2010. "State Policies That Pay: A Survey of School Finance Policies and Outcomes." Bethesda, MD: Editorial Projects in Education and Pew Center on the States.

Hoxby, Caroline M. 2001. "All School Finance Equalizations Are Not Created Equal." Quarterly Journal of Economics. 116 (4): 1189-1231.

Jackson, C. Kirabo, Rucker C. Johnson, and Claudia Persico. 2016. "The Effects of School Spending on Educational and Economic Outcomes: Evidence from School Finance Reforms." The Quarterly Journal of Economics 131(1): 157-218. doi:10.1093/qje/qjv036

Jackson, Kirabo. 2018. "Does School Spending Matter? The New Literature on an Old Question." NBER Working Paper No. 25368

Johnson, Rucker C., with Alexander Nazaryan. 2019. The Children of the Dream: Why School Integration Works. New York, NY: Basic Books and Russell Sage Foundation.

Kaushal, Neeraj, Katherine Magnuson, and Jane Waldfogel. 2011. "How Is Family Income Related to Investments in Children's Learning?" In Whither Opportunity: Rising Inequality, Schools, and Children's Life Chances, ed. Greg J. Duncan and Richard J. Murnane, chapter 9. New York, NY: Russell Sage Foundation.

Lafortune, Julien, Jesse Rothstein, and Diane Whitmore Schanzenbach. 2018. "School Finance Reform and the Distribution of Student Achievement." American Economic Journal: Applied Economics 10(2): 1-26. https://doi.org/10.1257/app.20160567

Lee, Jaekyung. 2002. "Racial and Ethnic Achievement Gap Trends: Reversing the Progress toward Equity?" Educational Researcher 31(1): 3-12.

Nelson, Charles A. III, and Margaret Sheridan. 2011. "Lessons from Neuroscience Research for Understanding Causal Links between Family and Neighborhood Characteristics and Educational Outcomes." In Whither Opportunity: Rising Inequality, Schools, and Children's Life Chances, ed. Greg J. Duncan and Richard J. Murnane, chapter 2. New York, NY: Russell Sage Foundation.

Reardon, Sean F. 2011. "The Widening Academic Achievement Gap between the Rich and the Poor: New Evidence and Possible Explanations." In Whither Opportunity: Rising Inequality, Schools, and Children's Life Chances, ed. Greg J. Duncan and Richard J. Murnane, chapter 5. New York, NY: Russell Sage Foundation.

Reardon, Sean F. 2016. "School Segregation and Racial Achievement Gaps." 2016. RSF: The Russell Sage 
Reardon, Sean F., Demetra Kalogrides, and Kenneth Shores. 2019. "The Geography of Racial/Ethnic Test Score Gaps." The American Journal of Sociology 124(4): 1164-1221. [Formerly CEPA Working Paper No. 16-10.] [Retrieved from Stanford Center for Education Policy Analysis: http://cepa.stanford.edu/wp16-10]

Reardon, Sean F., Andrew D. Ho, Benjamin R. Shear, Erin M. Fahle, Demetra Kalogrides, Haewon Jang, Belen Chavez, J. Buontempo, and R. DiSalvo. 2019. Stanford Education Data Archive (Version 3.0). http://purl.stanford.edu/db586ns4974. [I downloaded the following data files: (i) seda_geodist_pool_cs_v30.dta, (ii) seda_cov_geodist_pool_v30.dta, (iii) seda_metro_pool_cs_v30.dta, and (iv) seda_cov_metro_pool_v30.dta.]

Reardon, Sean F., Ericka S. Weathers, Erin M. Fahle, Heewon Jang, and Demetra Kalogrides. 2019. "Is Separate Still Unequal? New Evidence on School Segregation and Racial Academic Achievement Gaps." CEPA Working Paper No. 19-06. Retrieved from Stanford Center for Education Policy Analysis: http://cepa.stanford.edu/wp19-06.

Rothstein, Jesse. 2019. "Inequality of Educational Opportunity? Schools as Mediators of the Intergenerational Transmission of Income." Journal of Labor Economics 37(S1): 85-123.

Roy, Joydeep. 2011. "Impact of School Finance Reform on Resource Equalization and Academic Performance: Evidence from Michigan." Education Finance and Policy 6(2): 137-167.

Rueben, Kim, Megan Randall, and Aravind Boddupalli. 2018. "Budget Processes and the Great Recession: How State Fiscal Institutions Shape Tax and Spending Decisions." Research Report of State and Local Finance Initiative, Urban Institute (October).

Sanbonmatsu, Lisa, Jeffrey R. Kling, Greg J. Duncan, and Jeanne Brooks-Gunn. 2006. "Neighborhoods and Academic Achievement: Results from the Moving to Opportunity Experiment." Journal of Human Resources 41(4): 649-691.

Verstegen, Deborah A. 2011. "Public Education Finance Systems in the United States and Funding Policies for Populations with Special Educational Needs." Education Policy Analysis Archives 19(21).

Yinger, John, ed. 2004. Helping Children Left Behind: State Aid and the Pursuit of Educational Equity. Cambridge, MA: MIT Press.

Zhao, Bo. 2020. "Estimating the Cost Function of Connecticut Public K-12 Education: Implications for Inequity and Inadequacy in School Spending." Federal Reserve Bank of Boston Working Paper No. 206.

Zhao, Bo, and Nicholas Chiumenti. 2020. "Measuring Disparities in Cost and Spending across Connecticut School Districts." Federal Reserve Bank of Boston New England Public Policy Center Research Report No. 20-2. 


\begin{tabular}{|c|c|c|c|}
\hline $\begin{array}{l}\text { Number of Metro } \\
\text { Areas with } \\
\text { Measured Gap }\end{array}$ & $\begin{array}{c}\text { Average test-score } \\
\text { gap }\end{array}$ & $\begin{array}{l}\text { Average majority or } \\
\text { advantaged score }\end{array}$ & $\begin{array}{c}\text { Average minority or } \\
\text { disadvantaged } \\
\text { score }\end{array}$ \\
\hline
\end{tabular}

\begin{tabular}{|c|c|c|c|c|}
\hline \multicolumn{5}{|c|}{ Metro Areas with White-Black Test-Score Gap (Minority = Black) } \\
\hline New England & 28 & 61.0 & 34.6 & -25.7 \\
\hline Middle Atlantic & 69 & 55.3 & 15.9 & -39.6 \\
\hline East North Central & 151 & 57.7 & 13.0 & -44.4 \\
\hline West North Central & 111 & 58.3 & 18.6 & -39.5 \\
\hline South Atlantic & 156 & 61.6 & 17.2 & -44.3 \\
\hline East South Central & 88 & 51.0 & 2.1 & -49.0 \\
\hline West South Central & 115 & 57.0 & 9.6 & -47.5 \\
\hline Mountain & 65 & 52.8 & 17.0 & -35.0 \\
\hline Pacific & 75 & 54.9 & 8.1 & -46.4 \\
\hline All & 858 & 57.0 & 13.7 & -43.1 \\
\hline Weighted All & 858 & 69.5 & 20.3 & -49.2 \\
\hline \multicolumn{5}{|c|}{ Metro Areas with White-Hispanic Test-Score Gap (Minority = Hispanic) } \\
\hline New England & 28 & 47.7 & 34.6 & -12.6 \\
\hline Middle Atlantic & 68 & 47.3 & 16.5 & -31.1 \\
\hline East North Central & 163 & 36.1 & 13.5 & -22.5 \\
\hline West North Central & 116 & 43.4 & 18.6 & -24.6 \\
\hline South Atlantic & 154 & 37.5 & 17.8 & -19.6 \\
\hline East South Central & 84 & 30.4 & 2.3 & -28.4 \\
\hline West South Central & 126 & 38.7 & 9.4 & -29.6 \\
\hline Mountain & 81 & 51.1 & 18.0 & -33.0 \\
\hline Pacific & 83 & 51.7 & 7.5 & -44.5 \\
\hline All & 903 & 41.1 & 14.0 & -27.1 \\
\hline Weighted All & 903 & 51.6 & 21.7 & -29.9 \\
\hline \multicolumn{5}{|c|}{ Metro Areas with Not Economically Disadvantaged-Economically Disadvantaged Test-Score Gap } \\
\hline New England & 29 & 64.8 & 48.2 & -16.3 \\
\hline Middle Atlantic & 69 & 63.3 & 33.9 & -29.4 \\
\hline East North Central & 167 & 57.6 & 32.2 & -25.3 \\
\hline West North Central & 119 & 55.9 & 34.1 & -21.8 \\
\hline South Atlantic & 156 & 64.1 & 33.3 & -30.4 \\
\hline East South Central & 88 & 58.6 & 22.1 & -36.4 \\
\hline West South Central & 126 & 57.0 & 21.3 & -35.1 \\
\hline Mountain & 80 & 55.9 & 27.1 & -28.8 \\
\hline Pacific & 83 & 64.6 & 21.9 & -43.2 \\
\hline All & 917 & 59.6 & 29.4 & -30.1 \\
\hline Weighted All & 917 & 63.5 & 33.3 & -30.1 \\
\hline
\end{tabular}

Source: Author's calculations based on data sources listed in Appendix Table A2.

Note: Scores are in standardized units, multiplied by 100 ; that is, a gap value of 50 equals half a standard deviation difference in test scores. Test scores are normed relative to an elementary school cohort average defined by the Stanford Education Data Archive that is set equal to zero by definition. A test-score value of minus -50 therefore indicates a score that is half a standard deviation below the cohort average. Each panel reports simple averages, by division and overall, for metro areas included in each of the three test-score gap regression samples. The "Weighted All" row reports overall averages based on regression weights. 
Table 2. Race and Poverty Disparities in Average Metro Area, by Division

\begin{tabular}{|c|c|c|c|c|c|c|}
\hline & \multirow{2}{*}{$\begin{array}{c}\text { Number of } \\
\text { Metro Areas } \\
\text { with Measured } \\
\text { Gap }\end{array}$} & \multicolumn{2}{|c|}{ Minority-White Segregation } & \multicolumn{2}{|c|}{$\begin{array}{c}\text { Minority-White Poverty } \\
\text { Segregation }\end{array}$} & \multirow{2}{*}{$\begin{array}{l}\text { Percent Minority } \\
\text { Students }\end{array}$} \\
\hline & & $\begin{array}{c}\text { Between } \\
\text { Schools in } \\
\text { Average District }\end{array}$ & $\begin{array}{l}\text { Between } \\
\text { Districts in } \\
\text { Metro }\end{array}$ & $\begin{array}{c}\text { Between } \\
\text { Schools in } \\
\text { Average District }\end{array}$ & $\begin{array}{l}\text { Between } \\
\text { Districts in } \\
\text { Metro }\end{array}$ & \\
\hline \multicolumn{7}{|c|}{ Metro Areas with White-Black Test-Score Gap (Minority = Black) } \\
\hline New England & 28 & 1.2 & 7.7 & 1.9 & 14.5 & 5.1 \\
\hline Middle Atlantic & 69 & 2.4 & 10.6 & 1.7 & 13.3 & 7.9 \\
\hline East North Central & 151 & 2.3 & 10.6 & 2.6 & 11.9 & 7.3 \\
\hline West North Central & 111 & 1.7 & 4.1 & 3.2 & 5.7 & 5.3 \\
\hline South Atlantic & 156 & 10.4 & 5.7 & 8.1 & 3.4 & 25.7 \\
\hline East South Central & 88 & 7.9 & 11.1 & 5.4 & 4.7 & 26.3 \\
\hline West South Central & 115 & 6.1 & 7.5 & 5.2 & 7.1 & 17.3 \\
\hline Mountain & 65 & 0.7 & 0.7 & 3.9 & 1.7 & 1.8 \\
\hline Pacific & 75 & 1.4 & 1.8 & 4.4 & 5.6 & 2.9 \\
\hline All & 858 & 4.5 & 6.9 & 4.5 & 7.0 & 12.9 \\
\hline Weighted All & 858 & 9.9 & 13.8 & 7.9 & 11.9 & 23.6 \\
\hline \multicolumn{7}{|c|}{ Metro Areas with White-Hispanic Test-Score Gap (Minority = Hispanic) } \\
\hline New England & 28 & 1.7 & 10.7 & 2.2 & 14.0 & 8.7 \\
\hline Middle Atlantic & 68 & 1.8 & 8.1 & 1.6 & 11.5 & 7.9 \\
\hline East North Central & 163 & 1.8 & 4.2 & 2.2 & 7.5 & 6.6 \\
\hline West North Central & 116 & 2.4 & 5.1 & 3.6 & 4.8 & 11.5 \\
\hline South Atlantic & 154 & 5.2 & 1.2 & 6.9 & 1.9 & 12.9 \\
\hline East South Central & 84 & 2.3 & 1.4 & 4.7 & 2.3 & 4.7 \\
\hline West South Central & 126 & 3.2 & 6.0 & 4.5 & 5.3 & 32.0 \\
\hline Mountain & 81 & 6.1 & 4.8 & 6.7 & 3.0 & 31.5 \\
\hline Pacific & 83 & 6.7 & 10.1 & 6.8 & 7.5 & 32.5 \\
\hline All & 903 & 3.5 & 4.9 & 4.5 & 5.5 & 16.4 \\
\hline Weighted All & 903 & 6.5 & 7.9 & 7.9 & 9.0 & 22.7 \\
\hline
\end{tabular}

Source: Author's calculations based on data sources listed in Appendix Table A2.

Note: Measures of minority-white segregation reflect racial differences in exposure to minority students in schools or districts. Measures of minority-white poverty segregation reflect racial differences in exposure to low-income students in schools or districts; see text. "Weighted All" row reports overall average based on regression weights.

Table 2, continued: Characteristics of average metro area, by division

\begin{tabular}{cccccc} 
Number of & \multicolumn{2}{c}{ Poverty Segregation } & & & \\
Metro Areas & Between & Between & Income & Total School & Number of \\
with Measured & Schools in & Districts in & Students & Enrollment & School Districts \\
Gap & Average District & Metro & & & \\
\hline
\end{tabular}

\begin{tabular}{|c|c|c|c|c|c|c|}
\hline \multicolumn{7}{|c|}{ Metro Areas with Not Economically Disadvantaged-Economically Disadvantaged Test-Score Gap } \\
\hline New England & 29 & 3.0 & 14.9 & 30.3 & 31,189 & 32.1 \\
\hline Middle Atlantic & 69 & 3.2 & 11.5 & 35.6 & 36,199 & 25.3 \\
\hline East North Central & 167 & 6.5 & 8.9 & 40.4 & 17,752 & 14.1 \\
\hline West North Central & 119 & 5.0 & 4.8 & 37.5 & 10,743 & 10.9 \\
\hline South Atlantic & 156 & 9.7 & 3.0 & 53.1 & 25,246 & 4.0 \\
\hline East South Central & 88 & 6.5 & 4.1 & 56.0 & 12,408 & 4.8 \\
\hline West South Central & 126 & 6.8 & 6.1 & 54.9 & 22,398 & 9.8 \\
\hline Mountain & 80 & 9.4 & 5.2 & 42.7 & 18,232 & 7.9 \\
\hline Pacific & 83 & 9.0 & 7.5 & 47.3 & 43,500 & 17.3 \\
\hline All & 917 & 7.0 & 6.5 & 45.8 & 22,428 & 11.6 \\
\hline Weighted All & 917 & 9.0 & 8.2 & 45.0 & 39,293 & 15.9 \\
\hline
\end{tabular}

Source: Author's calculations based on data sources listed in Appendix Table A2.

Note: Poverty segregation reflects differences between low-income (free-lunch) and higher-income (non-free-lunch) students in exposure to low-income students. "Weighted All" row reports overall average based on regression weights. 
Table 3. Metropolitan-Area Test-Score Gaps between White and Black Students Estimated coefficients with robust standard errors below

\begin{tabular}{|c|c|c|c|c|}
\hline & \multicolumn{2}{|c|}{ Full Version } & \multicolumn{2}{|c|}{ Lean Version } \\
\hline & $(1)$ & $(2)$ & (3) & (4) \\
\hline \multicolumn{5}{|l|}{ School Finance: } \\
\hline \multirow[t]{2}{*}{ State Revenue Dollars per Student } & 5.66 & 5.80 & & \\
\hline & 5.49 & 4.49 & & \\
\hline \multirow[t]{2}{*}{ Progressivity of State Aid } & $4.61 * *$ & $4.20 * *$ & $4.83 * *$ & $2.77 *$ \\
\hline & 1.36 & 1.27 & 1.43 & 1.14 \\
\hline Progressivity interacted with metro average & $-39.2 * *$ & $-31.8 * *$ & $-39.2 * * *$ & $-27.4 * *$ \\
\hline district poverty & 11.9 & 10.3 & 10.4 & 8.6 \\
\hline \multirow[t]{2}{*}{ School instructional spending per pupil } & -0.56 & -1.44 & & \\
\hline & 0.82 & 0.76 & & \\
\hline \multicolumn{5}{|l|}{ School and District Segregation: } \\
\hline \multirow{2}{*}{$\begin{array}{l}\text { Average within-district Black-white segregation of } \\
\text { schools }\end{array}$} & -0.354 & -0.225 & & \\
\hline & 0.191 & 0.149 & & \\
\hline \multirow{2}{*}{ Between-district Black-white student segregation } & $-0.386 * *$ & $-0.193 *$ & & \\
\hline & 0.119 & 0.095 & & \\
\hline \multirow{2}{*}{$\begin{array}{l}\text { Average within-district Black-white poverty } \\
\text { segregation of schools }\end{array}$} & $1.22 * * *$ & $0.64 * * *$ & $0.91 * * *$ & $0.42 * *$ \\
\hline & 0.18 & 0.16 & 0.12 & 0.13 \\
\hline \multirow{2}{*}{ Between-district Black-white poverty segregation } & $1.12 * * *$ & $0.63 * * *$ & $0.84^{* * *}$ & $0.51 * * *$ \\
\hline & 0.13 & 0.12 & 0.12 & 0.10 \\
\hline Difference in student-teacher ratio of average & 0.004 & -0.378 & & \\
\hline Black/white student's school & 0.006 & 0.533 & & \\
\hline Difference in per-pupil instructional spending in & 1.77 & 2.13 & & \\
\hline average Black/white student's district & 2.08 & 1.76 & & \\
\hline \multicolumn{5}{|l|}{ Metro Characteristics and Parental Disparities: } \\
\hline \multirow[t]{2}{*}{ Fraction Black students in metro area } & 14.5 & 12.1 & -0.27 & 0.88 \\
\hline & 7.6 & 7.9 & 6.34 & 6.48 \\
\hline Difference between Black and white percentage & & $-1.39 * * *$ & & $-1.44 * * *$ \\
\hline parents with BA or more & & 0.16 & & 0.16 \\
\hline Difference between Black and white percentage & & $1.25 * *$ & & $1.35 * * *$ \\
\hline parents unemployed & & 0.36 & & 0.35 \\
\hline \multirow[t]{2}{*}{ Constant } & 9.9 & -8.5 & $56.1 * * *$ & $34.2 * * *$ \\
\hline & 44.7 & 36.3 & 3.1 & 3.7 \\
\hline Adjusted R-squared & 0.4172 & 0.6150 & 0.4177 & 0.6199 \\
\hline Number of observations & 734 & 426 & 858 & 515 \\
\hline
\end{tabular}

Source: Author's calculations based on data sources listed in Appendix Table A2.

Note: All equations estimated with weights inversely proportional to squared standard errors of dependent variable (test-score gap) published by SEDA. Errors clustered by state.

$* \mathrm{p}<0.05, * * \mathrm{p}<0.01, * * * \mathrm{p}<0.001$ 
Table 4. Metropolitan-Area Test-Score Gaps between White and Hispanic Students Estimated coefficients with robust standard errors below

\begin{tabular}{|c|c|c|c|c|}
\hline & \multicolumn{2}{|c|}{ Full Version } & \multicolumn{2}{|c|}{ Lean Version } \\
\hline & (1) & $(2)$ & (3) & (4) \\
\hline \multicolumn{5}{|l|}{ School Finance: } \\
\hline \multirow[t]{2}{*}{ State Revenue Dollars per Student } & 9.96 & 2.47 & & \\
\hline & 5.80 & 4.07 & & \\
\hline \multirow[t]{2}{*}{ Progressivity of State Aid } & $6.07 * *$ & 2.63 & $7.52 * * *$ & $3.48 *$ \\
\hline & 2.03 & 1.84 & 1.65 & 1.45 \\
\hline Progressivity interacted with metro average & $-40.1 * * *$ & -14.8 & $-52.0 * * *$ & $-19.8 *$ \\
\hline district poverty & 11.1 & 8.1 & 12.6 & 7.6 \\
\hline \multirow[t]{2}{*}{ School instructional spending per pupil } & 0.54 & 0.47 & & \\
\hline & 1.04 & 0.77 & & \\
\hline \multicolumn{5}{|l|}{ School and District Segregation: } \\
\hline Average within-district Hispanic-white segregation & 0.025 & -0.112 & & \\
\hline of schools & 0.273 & 0.156 & & \\
\hline Between-district Hispanic-white student & -0.136 & -0.034 & & \\
\hline segregation & 0.202 & 0.148 & & \\
\hline Average within-district Hispanic-white poverty & $0.959 * * *$ & $0.537^{* * *}$ & $0.969 * * *$ & $0.445 * * *$ \\
\hline segregation of schools & 0.208 & 0.089 & 0.157 & 0.100 \\
\hline Between-district Hispanic-white poverty & $1.030 * * *$ & $0.533^{* *}$ & $0.946 * * *$ & $0.520 * * *$ \\
\hline segregation & 0.177 & 0.156 & 0.116 & 0.098 \\
\hline Difference in student-teacher ratio of average & 0.025 & -0.129 & & \\
\hline Hispanic/white student's school & 0.016 & 0.714 & & \\
\hline Difference in per-pupil instructional spending in & -3.00 & -1.16 & & \\
\hline average Hispanic/white student's district & 2.42 & 1.78 & & \\
\hline \multicolumn{5}{|l|}{ Metro Characteristics and Parental Disparities: } \\
\hline \multirow{2}{*}{ Fraction Hispanic students in metro area } & $17.3 *$ & -4.6 & $14.31 * *$ & -6.03 \\
\hline & 8.1 & 7.5 & 5.04 & 4.65 \\
\hline Difference between Hispanic and white & & $-1.43 * * *$ & & $-1.48 * * *$ \\
\hline percentage parents with BA or more & & 0.14 & & 0.12 \\
\hline Difference between Hispanic and white & & $1.53 * *$ & & $1.56 * *$ \\
\hline percentage parents unemployed & & 0.52 & & 0.48 \\
\hline \multirow[t]{2}{*}{ Constant } & -55.2 & -9.1 & $34.7 * * *$ & $14.8 * * *$ \\
\hline & 47.3 & 34.8 & 3.1 & 2.9 \\
\hline Adjusted R-squared & 0.5254 & 0.7163 & 0.5351 & 0.7290 \\
\hline Number of observations & 774 & 430 & 903 & 521 \\
\hline
\end{tabular}

Source: Author's calculations based on data sources listed in Appendix Table A2.

Note: All equations estimated with weights inversely proportional to squared standard errors of dependent variable (test-score gap) published by SEDA. Errors clustered by state.

$* p<0.05, * * p<0.01, * * * p<0.001$ 
Table 5. Metropolitan-Area Test-Score Gaps between Not-Economically Disadvantaged and Economically Disadvantaged Students

Estimated coefficients with robust standard errors below

Full Version

Lean Version

(1)

(2)

(3)

(4)

School Finance:

State Revenue Dollars per Student

$6.42 \quad 5.04$

3.52

2.64

Progressivity of State Aid

$1.89 *$

0.93

Progressivity interacted with metro average

$-19.3 * *$

6.4

$3.04 *$

$3.78 * *$

$4.23 * *$

district poverty

1.14

1.16

1.43

School instructional spending per pupil

0.616

$-34.7 * * *$

$-33.9 * * *$

7.3

7.9

School and District Segregation:

Average within-district Black-white segregation of schools

0.164 *

0.688

0.761

0.635

Between-district Black-white student segregation

0.070

$0.121 *$

0.116

0.060

0.063

0.114

Average within-district Hispanic-white

$0.382 *$

0.060

segregation of schools

0.129

$0.283 * *$

Between-district Hispanic-white student

$-0.111$

0.103

segregation

0.084

$-0.184$

Average within-district poverty segregation of

$0.640 * *$

0.092

schools

0.104

$0.591 * * *$

$0.766 * * *$

$0.785 * * *$

Between-district poverty segregation

$0.589 * * *$

0.071

0.133

0.096

0.116

$0.432 * * *$

$0.846 * * *$

$0.626 * * *$

Difference in student-teacher ratio of average

$-0.013$

0.102

0.099

0.099

low-income/higher income student's school

0.008

$-0.891$

$-0.002$

0.883

Difference in per-pupil instructional spending in

0.002

$-0.005$

average low-income/higher income student's

district

\section{Metro Characteristics and Parental Disparities:}

Fraction low-income students in metro area

$\begin{array}{rccc}-13.3 & -21.2 * & 5.73 & -5.95 \\ 8.0 & 8.1 & 7.54 & 7.80 \\ & 0.261 * & & 0.230 \\ & 0.104 & & 0.116 \\ & 0.626 * * * & & 0.559 * * \\ & 0.128 & & 0.161 \\ 0.6 & -0.7 & 51.1 * * * & 40.7 * * * \\ 27.3 & 20.5 & 3.1 & 4.2 \\ & & & \\ 0.4933 & 0.5552 & 0.4375 & 0.4918 \\ 690 & 400 & 917 & 515\end{array}$

Adjusted R-squared 690

0.003

Difference between Black and white parents'

poverty rate

Difference between Hispanic and white parents'

poverty rate

Constant

Number of observations

Source: Author's calculations based on data sources listed in Appendix Table A2.

Note: All equations estimated with weights inversely proportional to squared standard errors of dependent variable (testscore gap) published by SEDA. Errors clustered by state.

$* \mathrm{p}<0.05, * * \mathrm{p}<0.01, * * * \mathrm{p}<0.001$ 
Table 6. District Test-Score Gaps between White and Minority Students, Not-Disadvantaged and Economically Disadvantaged Students Estimated coefficients with robust standard errors below

\begin{tabular}{|c|c|c|c|c|c|c|}
\hline & \multicolumn{2}{|c|}{ White-Black Gaps } & \multicolumn{2}{|c|}{ White-Hispanic Gaps } & \multicolumn{2}{|c|}{ NED-ED Gaps } \\
\hline & $(1)$ & $(2)$ & (3) & $(4)$ & $(5)$ & $(6)$ \\
\hline \multicolumn{7}{|l|}{ School Finance: } \\
\hline \multirow[t]{2}{*}{ State Revenue Dollars per Student } & 0.55 & 1.78 & 8.55 & 7.98 & 6.11 & 6.21 \\
\hline & 6.35 & 4.44 & 6.94 & 5.04 & 3.54 & 3.48 \\
\hline \multirow[t]{2}{*}{ Progressivity of State Aid } & -0.023 & 1.094 & 1.868 & 1.049 & -0.501 & -0.429 \\
\hline & 0.915 & 0.777 & 1.319 & 0.900 & 0.522 & 0.478 \\
\hline \multirow[t]{2}{*}{ Progressivity interacted with district poverty } & $-17.5 * *$ & $-18.5 * *$ & $-19.9 * *$ & $-7.2 *$ & $-11.0 * *$ & $-10.3 * *$ \\
\hline & 6.3 & 5.9 & 6.5 & 3.3 & 4.0 & 3.5 \\
\hline \multirow[t]{2}{*}{ School spending per pupil } & $1.338 * * *$ & 0.095 & $0.764 *$ & -0.144 & $0.435 *$ & $0.475 *$ \\
\hline & 0.372 & 0.256 & 0.338 & 0.184 & 0.213 & 0.219 \\
\hline \multicolumn{7}{|l|}{ School Segregation: } \\
\hline \multirow{2}{*}{ Within-district Black-white segregation of schools } & $-0.336 * *$ & $-0.220 * *$ & & & $0.209 *$ & 0.069 \\
\hline & 0.119 & 0.063 & & & 0.093 & 0.059 \\
\hline \multirow{2}{*}{$\begin{array}{l}\text { Within-district Hispanic-white segregation of } \\
\text { schools }\end{array}$} & & & 0.202 & -0.105 & $0.501 *$ & $0.257 *$ \\
\hline & & & 0.160 & 0.125 & 0.199 & 0.118 \\
\hline \multirow{2}{*}{$\begin{array}{l}\text { Within-district racial poverty segregation of } \\
\text { schools }\end{array}$} & $1.51 * * *$ & $0.85 * * *$ & $1.15^{* * *}$ & $0.69 * * *$ & & \\
\hline & 0.10 & 0.07 & 0.16 & 0.11 & & \\
\hline \multirow{2}{*}{ Within-district poverty segregation of schools } & & & & & $0.637 *$ & $0.810 * * *$ \\
\hline & & & & & 0.249 & 0.129 \\
\hline \multicolumn{7}{|l|}{ District Characteristics and Parental Disparities: } \\
\hline \multirow[t]{2}{*}{ Fraction minority or low-income students } & $0.106 *$ & 0.024 & $0.071 *$ & $-0.057 *$ & $-0.197 * * *$ & $-0.258 * * *$ \\
\hline & 0.052 & 0.042 & 0.033 & 0.027 & 0.032 & 0.031 \\
\hline Difference between minority and white & & $-1.13 * * *$ & & $-1.32 * * *$ & & \\
\hline percentage parents with BA & & 0.06 & & 0.08 & & \\
\hline Difference between minority and white & & $0.617 * * *$ & & $0.777^{* * *}$ & & \\
\hline percentage parents unemployed & & 0.155 & & 0.210 & & \\
\hline Difference between Black and white parents' & & & & & & $0.205 * * *$ \\
\hline poverty rate & & & & & & 0.025 \\
\hline Difference between Hispanic and white parents' & & & & & & $0.206 * * *$ \\
\hline poverty rate & & & & & & 0.03 \\
\hline \multirow[t]{2}{*}{ Constant } & 34.5 & 26.9 & -45.7 & -46.2 & 3.3 & -0.3 \\
\hline & 53.6 & 37.7 & 57.6 & 42.3 & 29.6 & 29.3 \\
\hline Number of observations & 5,271 & 5,242 & 6,949 & 6,913 & 7,989 & 4,905 \\
\hline Adjusted R-squared & 0.3638 & 0.6281 & 0.4025 & 0.6388 & 0.3499 & 0.4131 \\
\hline
\end{tabular}

Source: Author's calculations based on data sources listed in Appendix Table A3.

Notes: NED-ED gap refers to gap between students who are not economically disadvantaged and students who are economically disadvantaged. All equations estimated with weights inversely proportional to squared standard errors of dependent variable (test-score gap) published by SEDA. Errors clustered by state.

$* \mathrm{p}<0.05, * * \mathrm{p}<0.01, * * * \mathrm{p}<0.001$ 


\begin{tabular}{|c|c|c|c|c|c|}
\hline Variable & Mean & $\begin{array}{l}\text { Standard } \\
\text { Deviation }\end{array}$ & Variable & Mean & $\begin{array}{l}\text { Standard } \\
\text { Deviation } \\
\end{array}$ \\
\hline White-Black test-score gap & 57.7 & 21.2 & $\begin{array}{l}\text { Average within-district Hispanic-white segregation } \\
\text { of schools }\end{array}$ & 3.4 & 4.7 \\
\hline White average test score & 13.5 & 18.6 & $\begin{array}{l}\text { Between-district Hispanic-white student } \\
\text { segregation }\end{array}$ & 4.4 & 6.8 \\
\hline Black average test score & -44.1 & 18.9 & $\begin{array}{l}\text { Average within-district Hispanic-white poverty } \\
\text { segregation of schools }\end{array}$ & 4.6 & 5.5 \\
\hline State Revenue Dollars per Student & 8.5 & 0.3 & $\begin{array}{l}\text { Between-district Hispanic-white poverty } \\
\text { segregation }\end{array}$ & 5.4 & 7.9 \\
\hline Progressivity of State Aid & 1.6 & 0.8 & $\begin{array}{l}\text { Difference in student-teacher ratio of average } \\
\text { Hispanic/white student's school }\end{array}$ & -0.77 & 14.4 \\
\hline $\begin{array}{l}\text { Progressivity interacted with metro average } \\
\text { district poverty }\end{array}$ & 0.31 & 0.13 & $\begin{array}{l}\text { Difference in per-pupil instructional spending in } \\
\text { average Hispanic/white student's district }\end{array}$ & 0.08 & 0.28 \\
\hline School instructional spending per pupil & 6.0 & 1.6 & Fraction Hispanic students in metro area & 0.15 & 0.18 \\
\hline $\begin{array}{l}\text { Average within-district Black-white segregation of } \\
\text { schools }\end{array}$ & 5.6 & 8.2 & $\begin{array}{l}\text { Difference between Hispanic and white } \\
\text { percentage parents with BA or more }\end{array}$ & -12.6 & 7.8 \\
\hline Between-district Black-white student segregation & 7.9 & 11.4 & $\begin{array}{l}\text { Difference between Hispanic and white } \\
\text { percentage parents unemployed }\end{array}$ & 4.6 & 2.0 \\
\hline $\begin{array}{l}\text { Average within-district Black-white poverty } \\
\text { segregation of schools }\end{array}$ & 4.9 & 6.1 & $\begin{array}{l}\text { Test-score gap between not disadvantaged and } \\
\text { economically disadvantaged students }\end{array}$ & 60.7 & 13.5 \\
\hline Between-district Black-white poverty segregation & 7.1 & 9.8 & $\begin{array}{l}\text { Not economically disadvantaged average test } \\
\text { score }\end{array}$ & 29.5 & 17.3 \\
\hline $\begin{array}{l}\text { Difference in student-teacher ratio of average } \\
\text { Black/white student's school }\end{array}$ & -0.62 & 9.9 & Economically disadvantaged average test score & -31.1 & 15.2 \\
\hline $\begin{array}{l}\text { Difference in per-pupil instructional spending in } \\
\text { average Black/white student's district }\end{array}$ & 0.13 & 0.36 & $\begin{array}{l}\text { Average within-district poverty segregation of } \\
\text { schools }\end{array}$ & 6.9 & 6.3 \\
\hline Fraction Black students in metro area & 0.15 & 0.18 & Between-district poverty segregation & 6.5 & 7.4 \\
\hline $\begin{array}{l}\text { Difference between Black and white percentage } \\
\text { parents with BA or more }\end{array}$ & -11.6 & 6.6 & $\begin{array}{l}\text { Difference in student-teacher ratio of low- } \\
\text { income/higher income student's school }\end{array}$ & -1.0 & 15.3 \\
\hline $\begin{array}{l}\text { Difference between Black and white percentage } \\
\text { parents unemployed }\end{array}$ & 8.7 & 2.0 & $\begin{array}{l}\text { Difference in per pupil instructional spending in } \\
\text { average low-income/higher income student's } \\
\text { district }\end{array}$ & 69.3 & 213 \\
\hline White-Hispanic test-score gap & 40.0 & 19.8 & Fraction low-income students in metro area & 0.47 & 0.13 \\
\hline White average test score & 13.5 & 18.6 & $\begin{array}{l}\text { Difference between Black and white parents' } \\
\text { poverty rate }\end{array}$ & 26.8 & 5.9 \\
\hline Hispanic average test score & -26.4 & 16.9 & $\begin{array}{l}\text { Difference between Hispanic and white parents' } \\
\text { poverty rate }\end{array}$ & 19.9 & 5.1 \\
\hline
\end{tabular}

Source: See Appendix Tables A2 and A3.

Note: Sample size is 640 metro areas with the following exceptions: difference between Black and white or Hispanic and white percentage parents with BA or more or percentage parents unemployed or percentage parents in poverty (400). 


Table A2. Variable Definitions and Sources, Metro Area Analysis

\section{Variable}

Metropolitan-area test-score gaps between subgroups --> Dependent variables in regressions

\section{School Finance Variables:}

State revenue dollars per student

Progressivity of State Aid

Progressivity interacted with metro average district poverty

School instructional spending per pupil

\section{School and District Segregation:}

Average within-district racial segregation of schools

Between-district racial student segregation

Average within-district racial poverty segregation

Between-district racial poverty segregation

Difference in student-teacher ratio of average minority/white student's school

Difference in per-pupil instructional spending in average minority/white student's district

Average within-district poverty segregation of schools

Between-district poverty segregation

Difference in student-teacher ratio of average low-income/higher income

student's school

Difference in per-pupil instructional spending in average low-income/higher

income student's district

\section{Metro Characteristics and Parental Disparities:}

Fraction minority students in metro area

Difference between minority and white percentage parents with BA or more

Difference between minority and white percentage parents unemployed

Fraction low-income (free-lunch) students in metro area

Difference between black and white parents' poverty rate

Difference between Hispanic and white parents' poverty rate
Sources

Stanford Educational Data Archive Archive (SEDA) test scores file -- see full citation below.

Rutgers state data file. For all Rutgers state data, see text for description of calculations for multistate metro areas.

Estimated progressivity of state revenue distribution across districts (30\% poverty district / $0 \%$ poverty district): Rutgers state data file

Progressivity measure interacted with metro average district poverty. Source for school-age children living in poverty: Census SAIPE SEDA, average over 2008/09-2015/16

Author's calculations based on NCES (see district sources, Table A3) SEDA metro cov file, average of exposure measures over 2008/09-2015/16 Author's calculations based on NCES (see district sources, Table A3) SEDA metro cov file, average of exposure measures over 2008/09-2015/16 SEDA metro cov file, average over 2008/09-2015/16

SEDA metro cov file, average over 2008/09-2015/16

Author's calculations based on NCES (see district sources, Table A3)

SEDA metro cov file, average of exposure measures over 2008/09-2015/16

SEDA metro cov file, average over 2008/09-2015/16

SEDA metro cov file, average over 2008/09-2015/16

SEDA metro cov file, average over 2008/09-2015/16

SEDA metro cov file (ACS), average over 2008/09-2015/16

SEDA metro cov file (ACS), average over 2008/09-2015/16

SEDA metro cov file, average over 2008/09-2015/16

SEDA metro cov file (ACS), average over 2008/09-2015/16

SEDA metro cov file (ACS), average over 2008/09-2015/16

Note: "racial difference" refers to Black-white or Hispanic-white differences; "minority" refers to Black or Hispanic.

Full citations:

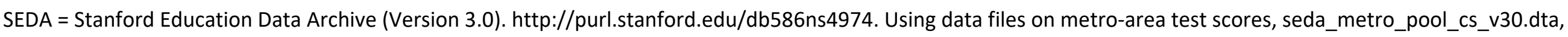
and on covariates at the metro-area level, seda_cov_metro_pool_v30.dta.

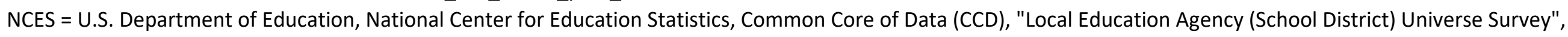
2009-10 v.2a; "Public Elementary/Secondary School Universe Survey", 2009-10 v.2a, 2017-18 v.1a.

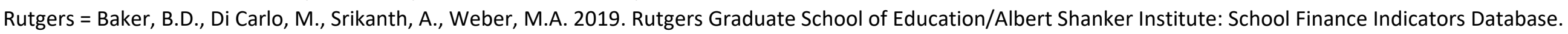
State Indicators Database retrieved from: http://www.schoolfinancedata.org. Averaging data for fiscal years 2008-2010. 


\section{Variable}

School-district test-score gaps between subgroups --> Dependent variables in regressions

\section{School Finance Variables:}

State revenue dollars per student

Progressivity of State Aid

Progressivity interacted with district poverty

School spending per pupil

\section{School Segregation:}

Within-district racial segregation of schools

Within-district racial poverty segregation of schools

Within-district poverty segregation of schools

\section{District Characteristics:}

Fraction minority or disadvantaged students

Difference between minority and white percentage parents with BA or more

Difference between minority and white percentage parents unemployed

Difference between Black and white parents' poverty rate

Difference between Hispanic and white parents' poverty rate
Sources

Stanford Educational Data Archive Archive (SEDA) test scores file -- see full citation below

Rutgers state data file. For all Rutgers state data, see text for description of calculations for multistate metro areas.

Estimated progressivity of state revenue distribution across districts ( $30 \%$ poverty district / $0 \%$ poverty district): Rutgers state data file

Progressivity measure interacted with district poverty. Source for school-age children living in poverty: Census SAIPE

Rutgers District Indicators database

Author's calculations based on NCES (see full citation below)

Author's calculations based on NCES

Author's calculations based on NCES

Author's calculations based on NCES

SEDA district covariates file

SEDA district covariates file

SEDA district covariates file

SEDA district covariates file

Note: "racial difference" refers to Black-white or Hispanic-white differences; "minority" refers to Black or Hispanic.

\section{Full citations:}

SEDA = Stanford Education Data Archive (Version 3.0). http://purl.stanford.edu/db586ns4974. Using data files on district test scores, seda_geodist_pool_cs_v30.dta, and district covariates, seda_cov_geodist_pool_v30.dta.

NCES = U.S. Department of Education, National Center for Education Statistics, Common Core of Data (CCD), "Local Education Agency (School District) Universe Survey", 2009-10 v.2a; "Public Elementary/Secondary School Universe Survey", 2009-10 v.2a.

Rutgers = Baker, B.D., Di Carlo, M., Srikanth, A., Weber, M.A. 2019. Rutgers Graduate School of Education/Albert Shanker Institute: School Finance Indicators Database. State Indicators Database retrieved from: http://www.schoolfinancedata.org. Averaging data for fiscal years 2008-2010. Local Education Agency (District) Fiscal Database v.2.0. Averaging data for fiscal years 2008-2010. 